\title{
Coastal and nearshore morphology, bedforms and sediment transport pathways at Teignmouth (UK)
}

\author{
V. van Lancker ${ }^{\mathrm{a}, \mathrm{b}, *}$, J. Lanckneus ${ }^{\mathrm{a}}$, S. Hearn ${ }^{\mathrm{c}}$, P. Hoekstra ${ }^{\mathrm{d}}$, F. Levoy ${ }^{\mathrm{e}}$, J. Miles ${ }^{\mathrm{f}}$, \\ G. Moerkerke ${ }^{\mathrm{a}}$, O. Monfort ${ }^{\mathrm{e}}$, R. Whitehouse ${ }^{\mathrm{c}}$ \\ ${ }^{a}$ Marine Geological Assistance (Magelas), Violierstraat 24, B-9820 Merelbeke, Belgium \\ ${ }^{\mathrm{b}}$ University of Gent, Renard Centre of Marine Geology, Krijgslaan 281, S-8, B-9000 Gent, Belgium \\ ${ }^{\mathrm{c}}$ HR Wallingford, Howbery Park, Wallingford, Oxon OX10 8BA, UK \\ ${ }^{\mathrm{d}}$ University of Utrecht, Institute for Marine and Atmospheric Research, Heidelberglaan 2, 3508 TC Utrecht, Nederland UK \\ ${ }^{\mathrm{e}}$ University of Caen, Unité Morphodynamique Continentale et Côtière, Station Marine, 54 Rue Du Dr Charcot, F-14530 \\ Luc-Sur-Mer, France \\ ${ }^{\mathrm{f}}$ Institute of Marine Studies, University of Plymouth, Drake Circus, Plymouth PL4 8AA, UK
}

Received 28 February 2001; accepted 9 March 2004

\begin{abstract}
The beach and nearshore area of Teignmouth (UK) has been the object of a multidisciplinary research project, COAST3D, carried out by 11 European institutions. This paper emphasises the sedimentological and morphological investigations of the intertidal and nearshore area using a variety of techniques. From the results presented, it is clear that the Teignmouth site is very dynamic. Sediment mobility is high during fair-weather conditions owing to the strong jet-like current flows associated with the presence of the narrow estuary mouth. The beach at Teignmouth can be categorised as composite with a dissipative low-tide terrace and a reflective upper beach. From surficial sediment sampling, selective transport processes were identified, imposed by the high current velocities at the estuary mouth. This process also leads to the formation of characteristic depositional lobes with poorly sorted sediment. From digital sidescan sonar mosaicing, cross-shore and longshore-oriented bedforms could be observed, with their characteristics being dependent on the pre-survey hydro-meteo conditions. Although the nearshore system is dominated by the jet-outflow, littoral drift processes can also be important. They proved to be important for beach morphological changes leading to a rythmic alongshore beach behaviour which was attributed to a reversal of the littoral drift imposed by a period of larger waves. Moreover, the influence of waves and associated longshore currents cannot be neglected as they form the link between different sedimentary environments. From combined side-scan sonar imagery and sediment trend analysis, residual sediment transport directions were identified. These showed that fair-weather and storm-dominated processes are needed to explain the textural and morphological differentiation at this site. Further analysis will be required to identify the different time-scales involved in producing these changes.
\end{abstract}

(C) 2004 Elsevier Ltd. All rights reserved.

Keywords: Teignmouth estuary; Nearshore and beach sediment and morphodynamics; Sand ripple profiler; RoxAnn; Digital side-scan sonar; Sediment trend analysis; COAST3D

\footnotetext{
*Corresponding author. University of Gent, Renard Centre of Marine Geology, Krijgslaan 281, S-8, B-9000 Gent, Belgium.

E-mail addresses: info@magelas.be, vera.vanlancker@UGent.be (V. van Lancker), sjh@hrwallingford.co.uk (S. Hearn), p.hoekstra@geog.uu.nl (P.Hoekstra),franck.levoy@geos.unicaen.fr (F. Levoy), j.r.miles@plymouth.ac.uk (J. Miles), olivier.monfort@geos.unicaen.fr (O. Monfort), rjsw@hrwallingford.co.uk (R. Whitehouse).
} 


\section{Introduction}

The beach and nearshore area of Teignmouth (UK) has been the object of a multidisciplinary research project, COAST3D, ${ }^{1}$ carried out by 11 European institutions (Soulsby, 1998). The COAST3D project was intended as a combined field and modelling study of the hydrodynamical, morphological and sedimentological behaviour of a beach and nearshore area. Teignmouth was chosen because of the irregular and three-dimensional (3D) nature of the coastline, with a rocky headland, nearshore banks, and an estuary mouth all adjacent to the beach with its sea defences.

Although, the data collected at Teignmouth are only valid on a temporal scale of 1 month, the results provide insight into the functioning of the coastal system and coastal process geomorphology in particular. As the site has many similar features to coastlines found in western and southern Britain, Ireland, northern and western France, northern Spain, Portugal, and Norway, the data will improve our understanding of the way in which coastal processes operate at these types of coastal sites. Moreover, the collected data set provides a good test for computer models both now and in the future. Similar investigations were carried out during the first phase of the project where research activities were focussed on the sandy beach and nearshore area of Egmond-aanZee, the Netherlands (Soulsby, 2000).

Teignmouth's beach and estuary system have been the subject of considerable interest since as early as the mid-19th century. One such early hydrographic survey of the area was made by Spratt (1856), who documented cyclic movements of bars in the estuary mouth. This theme was later taken up by Craig-Smith (1970) and Robinson (1975), who monitored bar movements at the entrance to the harbour for 10 years, in order to establish the cyclic nature of the process. Hydraulics research have made several studies on the area, including an examination of the harbour and the stabilisation of the entrance channels (Hydraulics Research Station, 1958), a sediment tracer experi-

\footnotetext{
${ }^{1}$ COAST3D is the acronym for Coastal Study of Threedimensional Sand Transport Processes and Morphodynamics.
}

ment (Hydraulics Research Station, 1966), and a model to examine how improvements to the harbour entrance would influence neighbouring beaches (Hydraulics Research Station, 1970). More recently, Wimpol (1989) deployed two moored current meters outside the estuary, and tide gauges in and out of the Teign estuary, in relation to works for a new outfall. They measured tidal currents and established the harmonic constituents for Teignmouth. Beach processes have also been studied in the framework of the British Beach and Nearshore Dynamics Programme (Davidson et al., 1993). In addition, the effect of a seawall on beach processes has been studied at Teignmouth by Miles et al. (1996). The estuary itself has been surveyed on several occasions (Hydraulics Research Station, 1970; Sea Sediments, 1979).

The main investigations at Teignmouth took place between 18 October and 26 November 1999 under a range of prevailing tide and wave conditions (Hearn et al., 2000; Whitehouse and Waters, 2000). This period included frequent and persistent storm wave conditions likely to produce a significant amount of morphological change.

Apart from the larger-scale geo-acoustical measurements and the sediment samplings in the nearshore, the COAST3D experiment was set up on the basis of three main transects to examine the cross-shore and longshore processes, and gradients in processes, and to provide data for model validation. The two cross-shore transects (north and south) form the basis of two contrasting linear arrays, one in the relatively open coast to the north and the other in the area where the 3D effects are expected to be greatest. The shore-parallel east transect was provided to analyse variations in the alongshore direction. Various fixed instruments for measuring conditions close to the boundaries of the area and two continuous monitoring frames (depth, waves, currents) were installed (Whitehouse et al., 2000).

This paper gives an introduction to the environmental setting of Teignmouth. In particular, it presents results on the morphological and sedimentological characteristics of the beach and the nearshore area obtained using a variety of 
techniques and methodologies. A single-beam echo sounder was used in the nearshore to determine the bathymetry and earlier recordings from a 'RoxAnn' system were used to determine parameters for the acoustical classification of the seafloor. A full coverage very-high-resolution digital side-scan sonar survey was carried out as a basis for a detailed morphological and sedimentological investigation. Grab samples were taken on a grid basis over the entire nearshore area, both to provide sediment size distribution as well as calibration of the RoxAnn data by visual inspection. The intertidal area was characterised through repetitive beach profile surveys, sediment sampling and measurements of the incident wave climate to quantify the morphodynamic features. More detailed processes were studied through the deployment of a large tripod enabling the measurement of the local hydrodynamics and morphology and including an autonomous sand ripple profiler to study bedform dimensions and migration rates. Finally, the results are compiled and interpreted in terms of the sediment dynamical behaviour of the site and residual sediment transport pathways are discussed.

Generally, the results provide a good characterisation of the physical characteristics and behaviour of a macro-tidal barred estuary-nearshore system in water depths ranging from 0 to $-7 \mathrm{~m}$ ACD (Admiralty Chart Datum, Teignmouth Approaches - approximately lowest astronomical tide). Other results of the COAST3D project are presented in accompanying papers in this volume of Nearshore and Coastal Oceanography. In these papers, physical processes will be dealt with in more detail.

\section{Environmental setting of the teignmouth site}

\subsection{Large-scale morphology}

The study area is situated at Teignmouth in the county of Devon, in the southwestern part of England. The town of Teignmouth is located on the north side of the mouth of the Teign estuary (Fig. 1) Teignmouth has a busy commercial port and local fishing fleet and is a popular location for beach users and watersports users (Whitehouse et al., 2000). Teignmouth is a good example of a coastal site with a multiplicity of potential Coastal Zone Management problems, i.e.--flood defence, navigation, sewerage disposal, tourism, environment-for which solutions to one problem must exist in harmony with the others.

The River Teign provides the main fluvial input into the estuary. The estuary channel is sinuous in the lower $1 \mathrm{~km}$ as it passes to the north of a large intertidal area ('The Salty'). On the south side of the estuary mouth the channel is constrained by a training wall and a rocky headland ('The Ness') locally composed of old red sandstone. To the south of 'The Ness' the coastline is rocky with isolated pocket beaches. To the north, there is a $2 \mathrm{~km}$ long beach backed by a seawall (the most recent development dates from 1977). The beach faces east-southeast into the English Channel. The beach has timber groynes along much of its length, and a 100-year old leisure pier situated mid-way along the beach in front of the town. Further to the north of the town, the beach is backed by the Brunel Seawall, which supports the main rail link to the southwest, and prevents further erosion of the cliffs. Far to the north, longshore sediment supply is blocked by a prominent headland, 'The

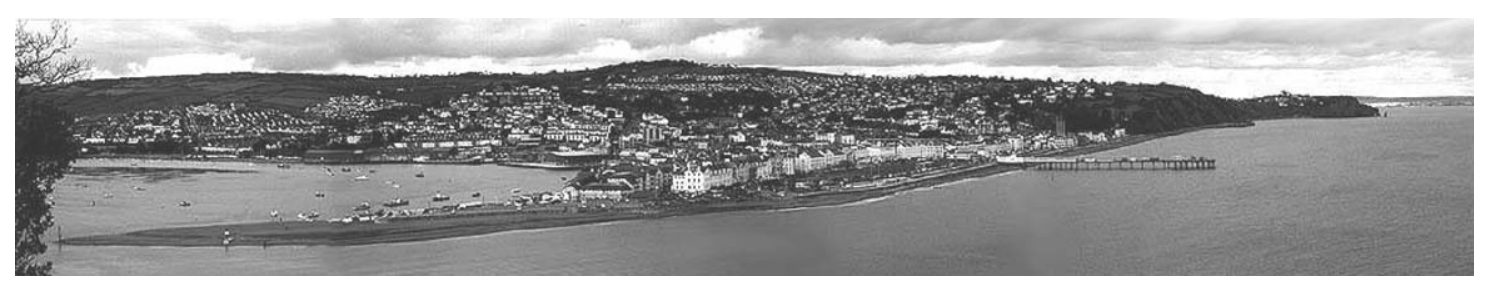

Fig. 1. The Teign estuary and nearshore looking north east. Photograph taken on 14 June 1999. Copyright South West Water (12094.5). 
Parson and Clerk'. Further interruption to the natural sediment transport regime takes place at 'Sprey Point', where a section of seawall protrudes beyond MWL (Miles et al., 1997).

The estuary mouth itself is narrow (about $130 \mathrm{~m}$ at mid-tide) and is characterised by a scoured channel, locally $-8 \mathrm{~m}$ ACD, whereas the approach channel through the ebb tidal shoal has a typical depth of $-2 \mathrm{~m}$ ACD. The distal end of the ebb tidal shoal extends to a distance of about $1 \mathrm{~km}$ from the estuary mouth and a semi-permanent sand bar. The ebb shoal and associated nearshore banks (locally called 'Poles') are morphologically active and were shown to move in a cyclic fashion by Spratt (1856) and Robinson (1975) in response to tidal and wave forcing. The long-term circulation of sediment in the nearshore banks present a hazard to navigation. For this reason, the offshore end of the navigation channel through the ebb tidal shoal and sand bar is presently dredged more or less daily with a small plough dredger operated from a tug. Despite this the sands can be treacherous and ships occasionally run aground on the ebb shoal. The navigation problem was recently highlighted on 27 April 1999, when a ship went aground on the outer sand banks before being refloated on a later tide.

Outside the influence of the ebb tidal shoal, the surrounding seabed has a gentle slope with relatively parallel contours and gradually to $-7 \mathrm{~m} \mathrm{ACD}$ in an offshore direction. On the north side of the estuary mouth there is a sand spit called 'Denn Point'. Just outside the estuary and along the northern shoreline another bar is present: the 'Spratt Sand' (Figs. 2 and 3). The latter is a persistent deposit of sand over a cobble pavement and is morphologically active as expressed by mobile ripples and dunes.

To the north of the estuary mouth and its associated sand bars, the meso- to macrotidal beaches generally have a flat, dissipative low-tide terrace, and a steep, reflective upper beach. The low-tide terrace extends approximately up to MLW, and often has a shallow bar. The upper beach gradient is approximately linear (Miles et al., 2000).

The beach and nearshore bank system comprises mixed sediments (sand and gravel) whilst the offshore sediment is typically very fine to fine sand.

Since, the Teignmouth site is regarded $3 \mathrm{D}$, the effects of the typical morphology on the hydrodynamics and sediment dynamics should not be underestimated. The morphological behaviour of the area is both affected by waves and tides; hence, it is most appropriate to classify the site as a mixed energy coast. The nearshore bars are expected to play an important role in the coastal development as they help to prevent severe shoreline erosion (Carter and Balsillie, 1983). The appearance of the nearshore bars varies because of the processes acting on a small (daily) temporal scale and on a large (yearly) scale (Robinson, 1975).

\subsection{Tidal characteristics}

Tides are semi-diurnal with mean tidal ranges of $1.7 \mathrm{~m}$ on neaps and $4.2 \mathrm{~m}$ on springs (Miles et al., 1997).

A strong jet-like current (with speeds of up to $3 \mathrm{~m} / \mathrm{s}$ ) flows from the estuary during the falling tide and for spring tide conditions (Wimpol, 1989; Walstra et al., 2000). Depth-averaged tidal currents at $1 \mathrm{~km}$ offshore did not generally exceed $0.3 \mathrm{~m} / \mathrm{s}$ (October/November 1999) (Whitehouse et al., 2000).

The exchange of water through the narrow estuary mouth results in locally high spring tide depth averaged current speeds that are in excess of $1.5 \mathrm{~m} / \mathrm{s}$ and maintain a deep scoured channel. Tidal current speeds off 'Denn Point' can reach $2 \mathrm{~m} / \mathrm{s}$ at $0.3 \mathrm{~m}$ above the bed, close to mid-flood and mid-ebb (Hydraulics Research Station, 1970). A tidal current curve for close to 'Denn Point' shows that flood and ebb tidal current speeds can be equally high, but that the flood has a somewhat longer duration. River discharge is generally less than $20 \mathrm{~m}^{3} / \mathrm{s}$ in summer, with peaks of $40-140 \mathrm{~m}^{3} / \mathrm{s}$ in autumn and winter (Miles et al., 1997; Whitehouse et al., 2000). High levels of river discharge can increase the ebb current speeds by $0.1 \mathrm{~m} / \mathrm{s}$ at the surface (Wimpol, 1989).

From measurements with instruments along the shoreface, it was shown that the mean tidal currents are weak, usually less than $0.2 \mathrm{~m} / \mathrm{s}$ (Levoy et al., 2000). The north-south component 


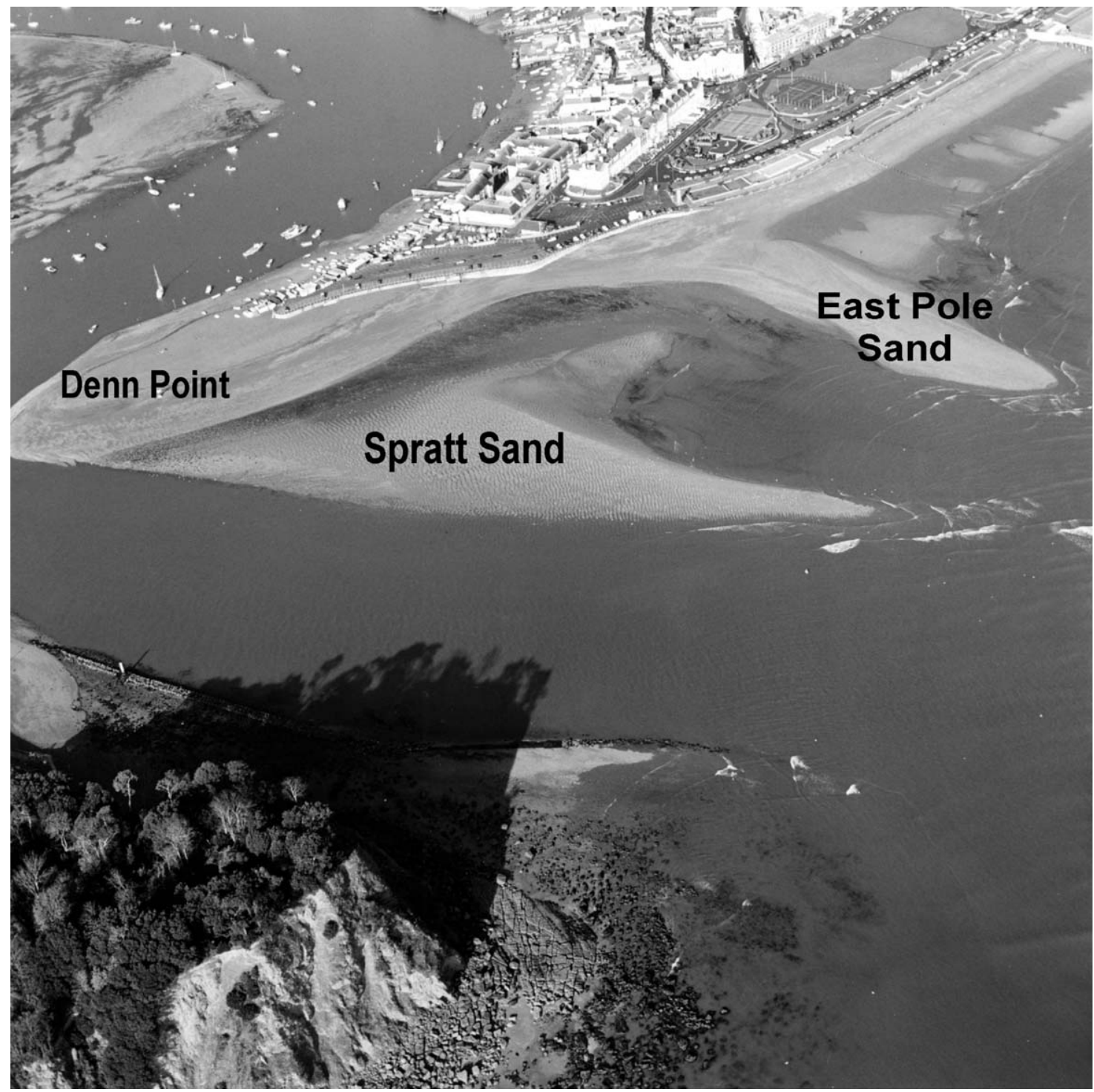

Fig. 2. The mouth of the Teign estuary showing 'Spratt Sand', 'East Pole Sand' and 'Denn Point'. View looking north west taken on 4 November 1998. Photograph copyright South West Water (11873.2).

is maximum at high tide and low tide. The eastward component is mostly weaker, usually less than $0.1 \mathrm{~m} / \mathrm{s}$.

In the flood channel, adjacent to the toe of 'Denn Beach', the velocities are larger and can exceed $1 \mathrm{~m} / \mathrm{s}$. Two reversals are observed near the high and low-tide stages and are characterised by very weak currents. During the ebb, the current is directed northeast whilst during the flood the currents are pointing in a southwest direction (Levoy et al., 2000). As there is more southerly flow than northerly flow, the residual current maintains the flood channel (Miles et al., 1997).

At 'Spratt Sand', field measurements showed that flow processes are strongly dominated by inand outflow processes in the estuary mouth and, consequently, the tidal flow is strongly bidirectional. The shoal fully emerges only during spring 


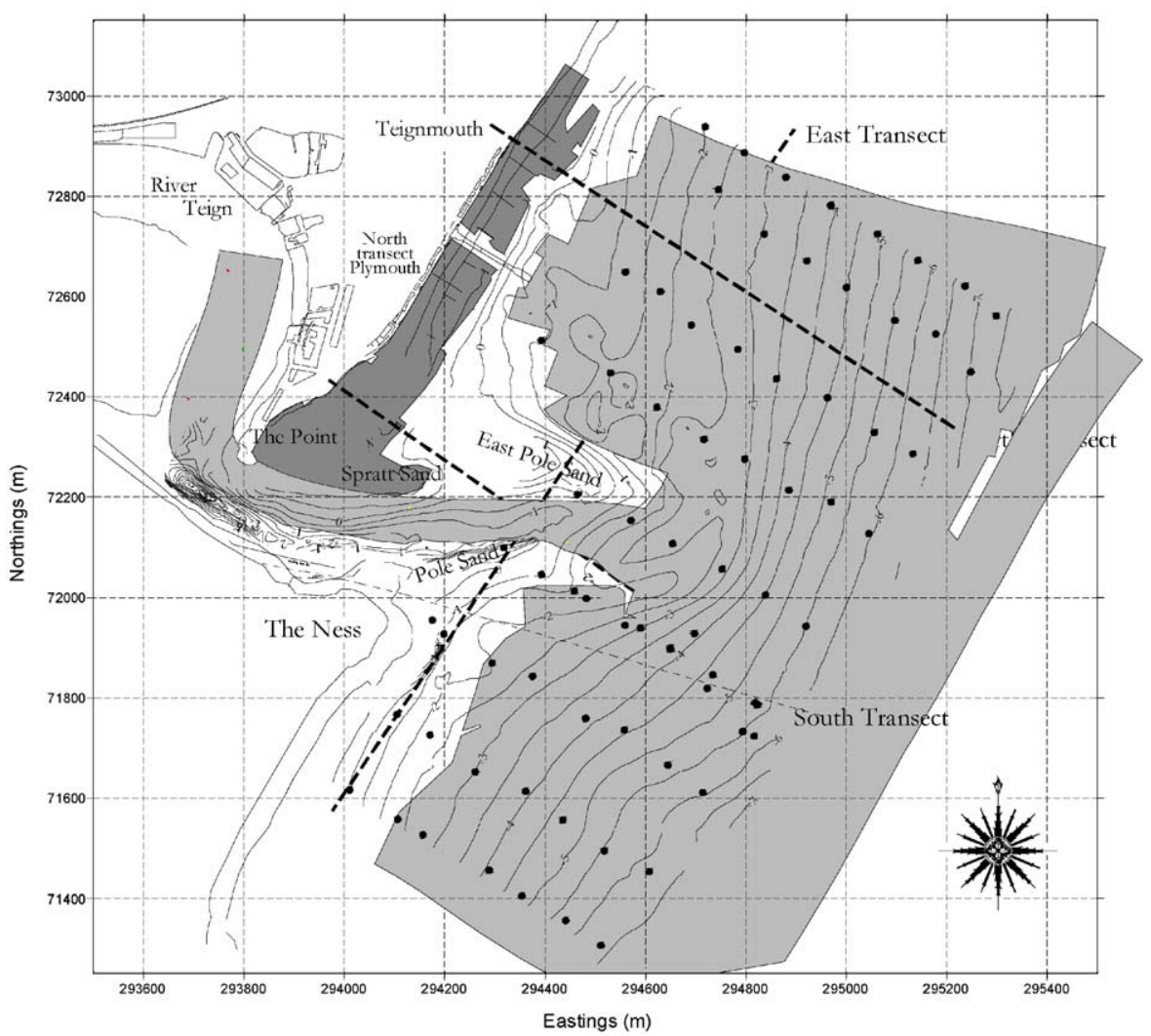

Fig. 3. Overview of the study area with an indication of the main morphological entities (bathymetry, 6-8/11/1999); the figure shows the position of the offshore samples (black dots) as well as the location of the east, north and south transects. The surveyed intertidal and offshore area is filled. Note the sinuous nature of the river Teign as it meanders and meets the open coastline.

tides whereas during neap tides most of the shoal remains submerged.

\subsection{Wave characteristics}

The wave climate is mainly characterised by small, short period wind-driven waves. Significant wave heights closer to the beach exceed $0.5 \mathrm{~m}$ for less than $10 \%$ of the year. During the COAST3D measurement period, a significant wave height of $0.5 \mathrm{~m}$ had an exceedance level of $50 \%$ whilst $1.2 \mathrm{~m}$ was reached during $10 \%$ of the time based on data from an offshore wave buoy. The orientation of the site to the prevailing wind shows that fairly infrequent winds from the northeast quadrant are responsible for generating storm waves, the rest of the time there can be low swell wave activity at the site.
Indeed, the larger waves result from strong easterly gales and these give a dominant longshore drift to the south (Miles et al., 1997). Rennie (1838) considered easterly gales as the critical factor in the sedimentation sequence, whilst Robinson (1975) proposed that it was the interaction between the tidal currents and the waves that led to the cyclic movement of the bars. Meteorological data obtained for the period 1980-1984 show the wind direction at Teignmouth to have three dominant directions (Burke, 1997). Winds from the west-southwest made up $20.6 \%$ of the total record while winds from the northwest made up $22.6 \%$ of the record. For $20 \%$ of this period, winds were in the northeast or east-northeast. The longshore current direction along the beach was found to match the offshore wave direction (Miles et al., 2000). 
From X-band radar measurements (Bell, 2000), it is shown that the regions around the sand bars clearly show wave refraction caused by the change in bathymetry.

\section{Methodology}

\subsection{Repetitive topographic beach measurements}

Three topographic surveys of the intertidal zone were conducted by the University of Caen, at low tide during spring tide conditions, at the beginning (25-27 October), at mid-time (the 8-10 November) and at the end of the experimentation period (2325 November) (dark grey zone in Fig. 3). A Trimble Survey Controller ${ }^{\mathrm{TM}}$ based on a global positioning system (GPS) was used. Two dualfrequency Trimble 4400 GPS receivers were used. The first one, the base, remained unmoved during the survey period and was located over a point at the end of Teignmouth Pier whose coordinates were known. The second one, the rover, was moved to the zone of interest to perform the topographic survey. Fixed during the survey, the two receivers tracked at least four similar satellites which provided the position of the rover receiver relative to the base. By radio link, the base observation was transmitted to the rover receiver which enabled real-time positioning.

HR Wallingford established control points, distributed on the promenade behind the beach and elsewhere locally, using a Geodimeter $440\left(1^{\prime \prime}\right.$ Total Station) and a Wild NA28 Auto level $(1.5 \mathrm{~mm} / \mathrm{km}$ double run surveyed) (Whitehouse et al., 2000). During the site calibration process, a number of these control points were also observed during each beach survey with GPS. Using this technique, the scattering of the $X, Y$ co-ordinates of the control points were less than $4 \mathrm{~cm}$ and smaller than $1 \mathrm{~cm}$ for the $Z$ co-ordinates.

In practice, the measurements are also affected by the field technique. Because of the tide conditions, the survey could only be carried out during a few hours every day. To improve the survey speed, the rover receiver was mounted, most of the time, on a small trailer pulled by a four-wheeled motorcycle (Quad Bike). In this case, the actual difference in elevation between the reference level of the GPS receiver and the beach, measured before each survey, could vary with the soil resistance characteristics influencing the trailer wheels penetration. As a consequence differences in elevations smaller than $10 \mathrm{~cm}$ should not be considered as significant.

\subsection{Measurements of bedform dimensions and dynamics at 'Spratt Sand'}

An almost continuous time series of bedform dimensions were collected at one spot on 'Spratt Sand'. To collect local hydrodynamical and morphological information a large tripod was deployed in a field of ripples and dunes close to (and north of) the main channel of the inlet (see Fig. 3, location $293952 \mathrm{~m} \mathrm{E}, 72218 \mathrm{~m} \mathrm{~N}$, ACD, $1.21 \mathrm{~m})$. The tripod measured waves and water levels (pressure sensor), horizontal flow velocities (two EMFs at a height of about $1 \mathrm{~m}$ above the bed), bedform dimensions and migration rates (Autonomous Sand Ripple Profiler, ASRP of Proudman Oceanographic Laboratory) and suspended sediment load (ABS and OBS). The ASRP continuously recorded ripple profiles over a transect of $3.5 \mathrm{~m}$, with time intervals between 2 and $5 \mathrm{~min}$ and over a total period of 28 days. Since the ASRP was installed at a height of about $1 \mathrm{~m}$ above the bed, data for part of the tidal cycle are missing when the shoal gradually submerges or emerges during rising and falling tides, respectively. Further details about measuring techniques, bedform dimensions and the application of dune tracking techniques to compute bedload transport is given by Hoekstra et al. (2004).

\subsection{Bathymetry, RoxAnn}

A baseline bathymetric survey of an area of $1.5 \times 1 \mathrm{~km}^{2}$ (long side parallel to the coastline) offshore of the estuary mouth, and including the port approaches, was completed in June 1998 by H.R. Wallingford. The survey was carried out with the $16 \mathrm{~m}$ HRW vessel 'Sir Claude Inglis' using DGPS position fixing (Trimble 4000 series) and a single frequency $(208 \mathrm{kHz})$ echo sounder (Raytheon DE719C). A line spacing of $25 \mathrm{~m}$, 
generally normal to the coastline, provided adequate spatial resolution. There were three crosscheck lines equi-spaced through the area at $250 \mathrm{~m}$ intervals, as well as random 'zigzag' lines in the main channels both seaward of 'The Point' and in the estuary areas (Whitehouse et al., 2000). Additional comprehensive surveys were completed at the beginning and end of the Pilot Study (March 1999). During the course of the Main study in October-November 1999, four surveys were completed (Table 1).

During the surveys a number of calibrations were carried out to meet high resolution requirements:

- twice daily echo sounder 'bar checks' to calibrate the unit for seawater density and vessel draft changes;

- daily DGPS navigation system checks against hard detail such as co-ordinated points on quaysides;

- twice daily water level board readings to calibrate and check the operation of the two automatic tide gauges located on the seaward end of Teignmouth Pier and at the New Quay in the inner harbour.

Measurements at sea were generally made under calm or slight wave and swell sea states. Inner harbour bathymetry was always made in calm conditions.

The bathymetry of each of the four surveys was first edited for 'data spikes' due to aeration or other mid-water reflections, and then corrected for wave action by using a rolling average algorithm. Corrections for tidal height were then made, and the depths were reduced to Chart Datum for the site. Generally, the position accuracy was better than $2 \mathrm{~m}$, whilst the accuracy of the echo sounder is quoted as $0.5 \% \pm 2.5 \mathrm{~cm}$ of the indicated depth.
The depth data collection was nominally at $10 \mathrm{~Hz}$. This rate produces a data set that is obviously too large to plot sensibly, or for efficient terrain modelling. Hence, the data are 'thinned' by specialist software to reduce it by a 'least depth' routine up to a scale suitable for further processing and representation. It should be noted that all 'thinned' data sets contained depth data to a $0.01 \mathrm{~m}$ resolution, but rounded up or down to $0.1 \mathrm{~m}$ before being presented on the large-scale paper charts.

For each of the four surveys, a $0.01 \mathrm{~m}$ resolution 1:500 data set was used for contour calculation and 3D-model presentation (SURFER ${ }^{\mathrm{TM}}$ ). Gridding was performed on a $5 \times 5 \mathrm{~m}^{2}$ grid using triangulation techniques.

In parallel with the June 1998 bathymetric survey, a seabed classification survey was made using the USP RoxAnn acoustic system. Data in the form of 'E1' roughness and 'E2' hardness were recorded from a Koden CVS106 colour $120 \mathrm{kHz}$ echo sounder and data were recorded at $0.33 \mathrm{~Hz}$ (max depth $80 \mathrm{~m}$, range scale $0-160 \mathrm{~m}$, gain 13). The transducer from the Koden was mounted through the hull on the port side of the vessel amidships. The 'E1' and 'E2' data were calibrated using visual identification of seabed grab samples and a sieve analysis was performed on 25 selected samples. A map of the sediment distribution, categorised as Fine Sand, Medium Sand, Coarse Sand, Stones, Sand and Stones and Rock was produced (Whitehouse et al., 2000) and was compared with the sedimentological investigation of November 1999.

\subsection{Nearshore grab sampling}

The survey platform, HRW 'Sir Claude Inglis' allowed a detailed sampling of the surficial

Table 1

Overview of the bathymetric surveys

\begin{tabular}{llll}
\hline & Date & Tidal conditions & Specific hydro-meteo conditions \\
\hline 1 & $27-28 / 10 / 1999$ & Spring tide & \\
2 & $6-8 / 11 / 1999$ & Spring tide & Preceded by a 6-day NE gale \\
3 & $16-19 / 11 / 1999$ & Neap tide (parts of East Pole Sand were missed out) & \\
4 & $24-25 / 11 / 1999$ & Spring tide & \\
\hline
\end{tabular}


Table 2

Timetable of the grab sampling and tidal conditions

\begin{tabular}{ll}
\hline Date & $4,6-7 / 11 / 1999$ \\
\hline Nearshore samples (71) (h:min) & $4 / 11: 11: 35-14: 03$ GMT (flooding phase of the tide) \\
& $6 / 11: 12: 46-14: 29$ GMT (flooding phase of the tide) \\
Tide (h:min) and tidal level (m ACD) & $7 / 11: 11: 59-12: 31$ GMT (flooding phase of the tide) \\
& $4 / 1:$ HW at 03:26 (3.9 m) and 15:42 GMT (4.3 m) \\
$6 / 1:$ HW at 05:04 (4.5 m) and 17:17 GMT (4.6 m) \\
7/11: HW at 05:43 (4.6 m) and 17:56 GMT (4.7 m) \\
\hline
\end{tabular}

sediments on 4-7 November 1999. In total, 71 samples were recovered using a 21 Van Veen galvanised grab, lowered by hand to the seabed (Table 2). The samples were taken along crossshore transects up to $500 \mathrm{~m}$ offshore and dissecting the different morphological entities. The samples were analysed using a laser diffractometer and a series of sieves for the coarser fractions. The nearshore samples were generally taken during the flood tide.

In the laboratory, the samples were dried and split up to a representative sample of $200 \mathrm{~g}$. This amount was sieved on a $1700 \mu \mathrm{m}$ mesh. After determination of the weight percentage of the bulk coarser fraction, mainly constituted of shell fragments, the sample was again split to an amount of $5-10 \mathrm{~g}$. This fraction was analysed using a laser diffractometer (Malvern Inc., 1986). A lens with a focal length of $1000 \mathrm{~mm}$ was used allowing a measuring coverage of $19.4-1880 \mu \mathrm{m}$. For samples containing a large fraction of coarser material, an amount of $50 \mathrm{~g}$ was mechanically sieved using a rack of $1400-50 \mu \mathrm{m}$ meshes on a $1 / 4$ phi interval.

For each of the samples several statistical parameters were determined. The mean, sorting, skewness and kurtosis were calculated using the moment measures (Seward-Thompson and Hails, 1973) on the whole sediment distribution as well as restricted to the grain fraction (Kranck and Milligan, 1991) and using the Folk and Ward (1957) method. The grain-size parameters derived from laser diffractometry are somewhat coarser than the ones that would be obtained from sieve analysis results. Comparative analysis of the laser diffractometry and sieving results on a number of samples from the Teignmouth area showed that the $d_{50}$ values obtained with laser diffraction were generally \pm 0.21 phi coarser than the values obtained by dry sieving. This offset value has previously been described and is attributed to the fact that different properties of the same material are being measured (Konert and Vandenberghe, 1997).

\subsection{Digital side-scan sonar recordings}

On 4-5 November 1999 and repeated on 18 November, the consultancy firm Magelas, deployed a GeoAcoustics dual-frequency digital side-scan sonar at frequencies of 100 and $410 \mathrm{kHz}$. Due to its higher resolution, the $410 \mathrm{kHz}$ registration was selected for the operations and a slant (oblique) range of $65 \mathrm{~m}$ was chosen. Side-scan sonar technology enables the development of a planar view of the sea floor in order to detect surface sediment textures and is also suitable to visualise small-scale morphological features. All recordings were stored digitally. Navigation and positioning was performed using a high-accuracy DGPS system.

The acquisition was accomplished by a digital PC-based system running ISIS software (Triton Technology Inc.). The system converts the incoming analogue data into a digital format. It samples the incoming data at a high frequency and processes them before storage and display. As the system receives positioning information, a geocoded image is obtained which means that the geographic position of each pixel is known. During the first survey (4-5 November 1999), 15 tracks were sailed in a cross-shore direction. 
During the second survey on 18 November 1999, the area of interest was covered by 10 lines parallel to the coast. Both surveys included a profile along the river Teign.

For the data processing Vista, Triport and Delph Map software (Triton Technology Inc.) was used. The geocoded acquisition allowed the realisation of fully rectified images (scale- and angle-corrected). As the tracklines were closely spaced, a full coverage very-high resolution mosaic of the area was produced. Finally, a composite map was created visualising the rectified side-scan sonar mosaic, detailed bathymetry and a superposition of the sampling points and the locations of the measuring frames. HR Wallingford recorded the detailed bathymetry on 16,17 and 19 November to coincide with the second period of side-scan sonar acquisition.

\section{Sedimentology of the intertidal area and nearshore}

\subsection{Sediments in the intertidal area}

Robinson (1975) reported that the grain-size on the beach is mainly coarse sand with a diameter of $400 \mu \mathrm{m}$ with some small shingle, diameter 5$50 \mathrm{~mm}$. Within the COAST3D framework, samples were taken along the beach together with a detailed survey of the topography. A contour plot of the beach topography in an area south of the pier and a contour plot of the grain-size distribution are shown in Fig. 4. The alongshore uniform nature of the steep upper beach and the low-tide terrace (see Section 5.1) is illustrated by the break in slope and associated contour lines running from SW to NE. At the slope break, a marked change in

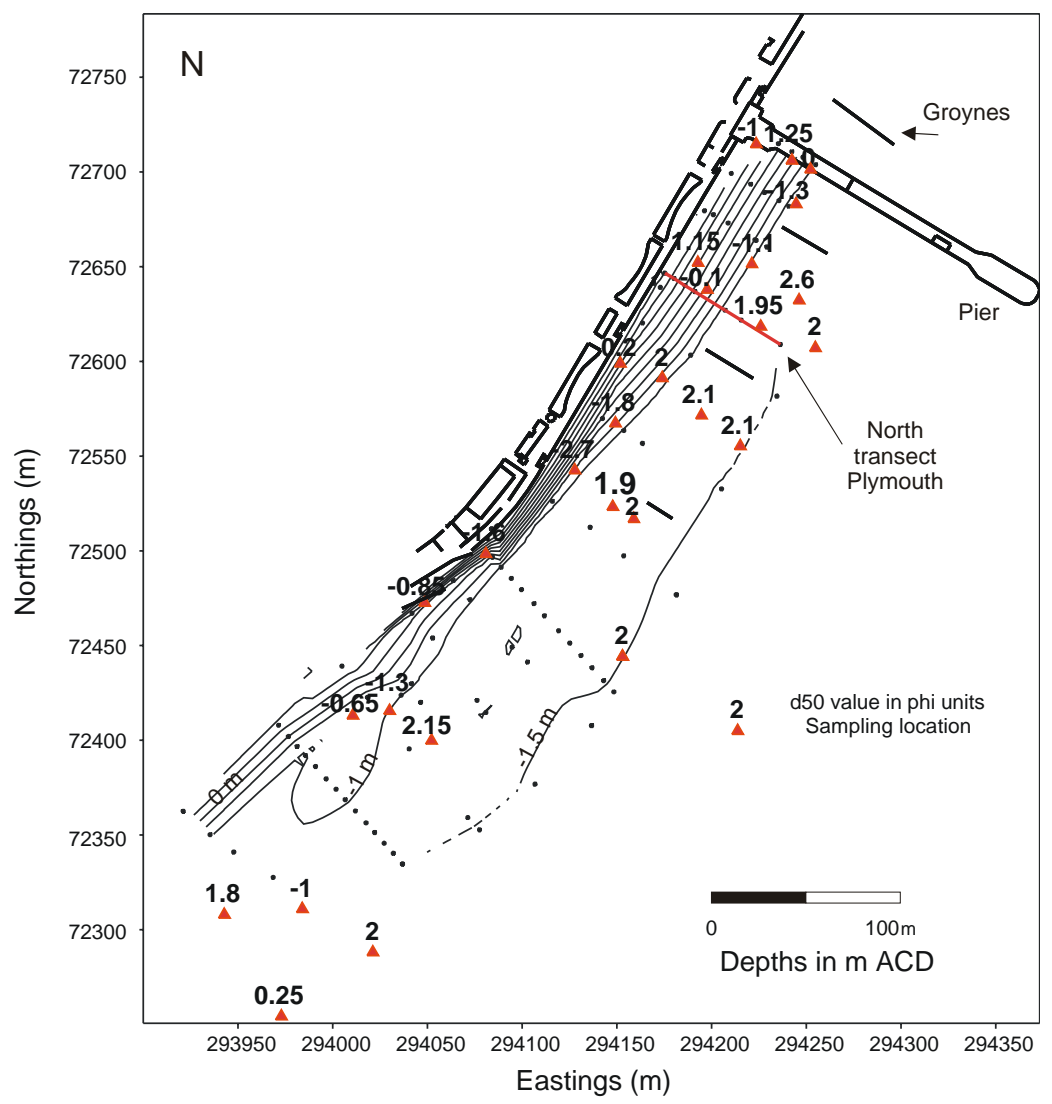

Fig. 4. Contour plot of the topography superimposed with the median grain-size (in phi) of the sampling points (results for 29/10/ 1999). The dots represent the topographic data; the triangles the sampling locations. 


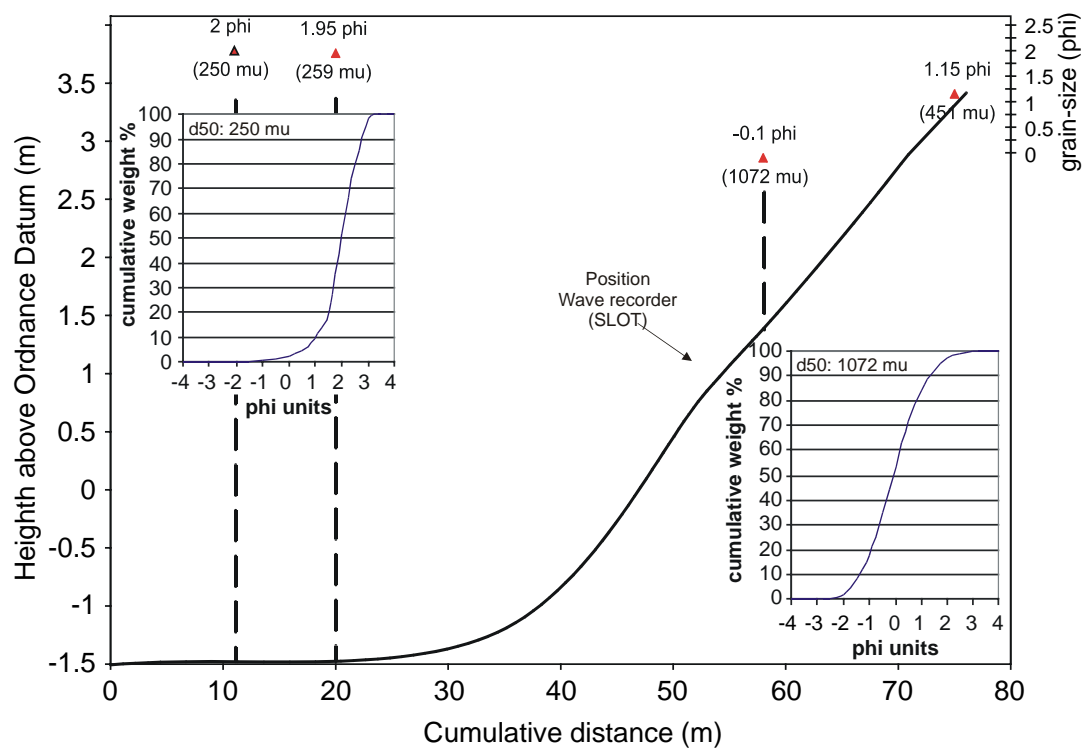

Fig. 5. Intertidal beach profile along the Plymouth north transect (location, see Fig. 3), showing the low-tide terrace, the position of the SLOT wave recorder and the position of four sediment samples. Also indicated is the sediment grain-size and two cumulative distribution curves respectively representative of the low-tide terrace and the upper beach.

sediment composition occurs all the way along the beach, from fine sand on the low-tide terrace, to coarse sand on the upper beach (Fig. 5). Lower beach sands have a typical $d_{50}$ of $250 \mu \mathrm{m}$, whilst the upper beach is characterised by $d_{50}$ values around $1100 \mu \mathrm{m}$.

The intertidal shoal, 'Spratt Sand' (see Figs. 2 and 3) partly consists of a gravelly substratum covered by a thin layer of sand (locally $10-30 \mathrm{~cm}$ thick) having a median grain-size varying between 250 and $300 \mu \mathrm{m}$. In some cases, the sand-gravel mixture has a median grain-size of about $1100 \mu \mathrm{m}$. However, if the coarse-grained material (> $850 \mu \mathrm{m})$ is removed from the samples, the median grain-size appears to be around $200 \mu \mathrm{m}$.

\subsection{Spatial distribution of the surficial sediments in the nearshore}

Generally, the nearshore (subtidal) area off Teignmouth is characterised by fine, well-sorted sands (125-250 $\mu \mathrm{m})$ (Fig. 6). However, the beach and nearshore bank system are composed of mixed sediments and at the estuary mouth, the mean grain-size varies in the range of very coarse sands up to gravelly deposits of $4000 \mu \mathrm{m}$. Of interest is the presence of three coarse-grained lobes from which the sediments gradually become finer in an offshore direction. The area of influence of the central lobe extends farthest offshore. The occurrence of these lobes presumably reflects the historic shifts in the nearshore banks and channels from which the lobes are derived. Outside the lobes no significant grain-size differentiation in the nearshore sediments is observed. The sorting is moderate to poor in the lobes and moderate to well sorted closer to the coast (Fig. 7). From the distribution pattern of the median $\left(d_{50}\right)$ values, the finest sediments occur in the lee sides of the lobes.

Fig. 8 represents a cross-shore profile, $100 \mathrm{~m}$ north of and parallel to the south transect (Fig. 3), showing the relation between the morphology and the grain-size characteristics. The median diameter $\left(d_{50}\right)$ is represented in $\mu \mathrm{m}$, the sorting in phi units. The depth is referenced to $\mathrm{m} \mathrm{ACD}$. On the plot of the $d_{50}$ values, also the occurrence of the tubeworm Lanice conchilega (L) is indicated as found in the samples. Note that they only occur where fine sands predominate.

In order to gain insight into the processes governing the development of a coastal system, the volume percentages of each quarter phi 


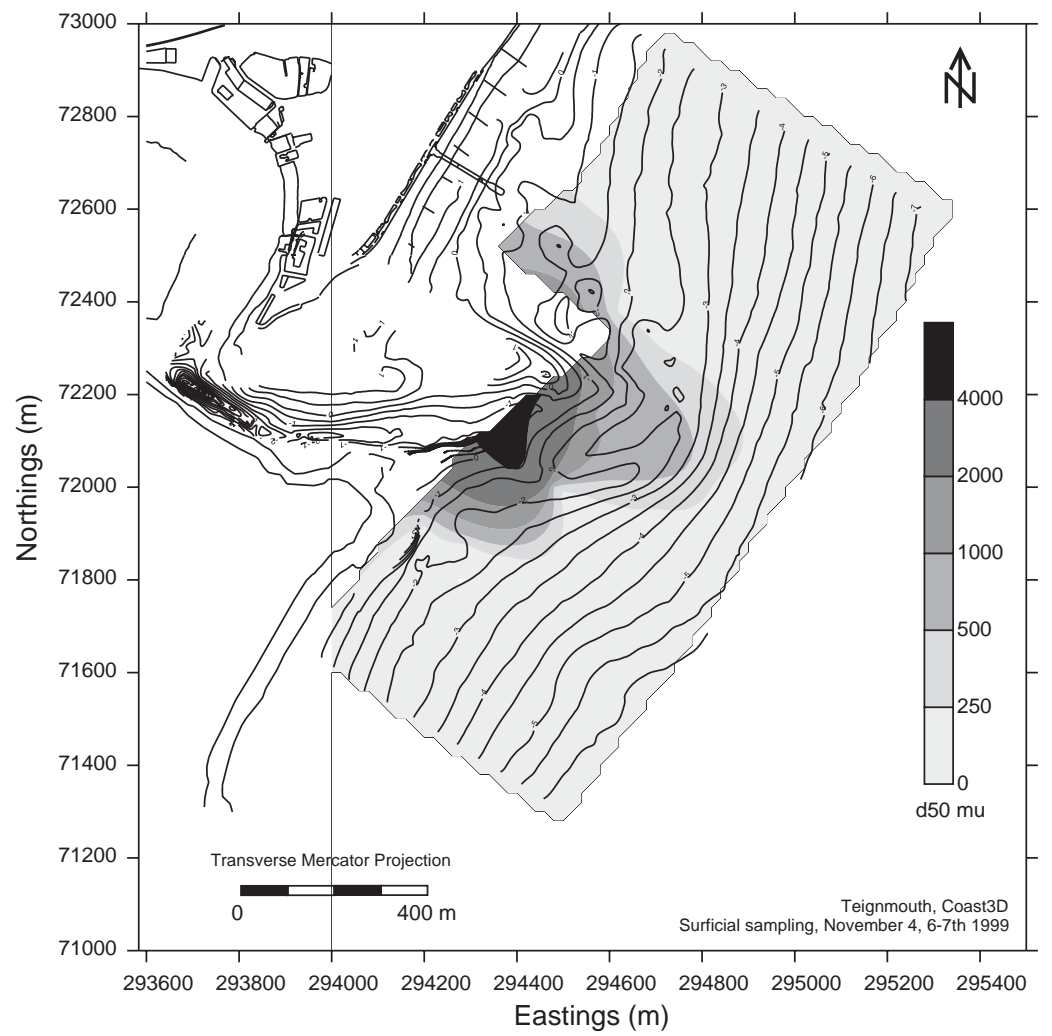

Fig. 6. Contour plot of the areal distribution of the median grain-size of the surficial sediments ( $>2$ mm: gravel; $1-2 \mathrm{~mm}$ : very coarse sand; $500-1000 \mu \mathrm{m}$ : coarse sand; $250-500 \mu \mathrm{m}$ : medium sand; $125-250 \mu \mathrm{m}$ : fine sand).

fraction of the sediments were plotted along the cross-shore profile represented in Fig. 8. A depletion of fractions may be attributed to a transport of sediments, either by currents or by waves.

From the distribution map of the median diameter (Fig. 6), it is clear that the surficial sediments of the central lobe are the coarsest and represent a different sedimentary environment than the sediments situated further offshore. A fraction analysis along the central lobe shows a clear winnowing trend at the estuary mouth. Grains in the range of $300-350 \mu \mathrm{m}$ are winnowed in the shallowest part and are deposited downslope. An enrichment of the fractions $300-210 \mu \mathrm{m}$ occurs at the foot of the slope, whilst finer grains are in equilibrium deeper than $-5 \mathrm{~m}$ ACD. The observed grain-size distribution at the main central lobe (as well as the other lobes) can be the result of the selection process on a mouthbar/deltaic body of sediment due to reducing outflow velocities in a seaward direction. Afterwards, winnowing of fine sediments (for example by waves) can take place removing the finer fractions. In that case, the observed distribution is the result of deposition of coarse-grained bedload material, suspension fallout and reworking of the fine-grained deposits.

The sorting is best in the offshore regions and areas shallower than $-2 \mathrm{~m}$ ACD. Between $-2 \mathrm{~m}$ and $-5 \mathrm{~m} \mathrm{ACD}$, an admixture of fractions may be present. This may be due to a coarser matrix sometimes enriched with finer grains.

Bimodal sediments can occur where a thin veneer of fine sands is deposited over coarsegrained ripple fields.

Comparison with the results of the acoustical seabed classification based on RoxAnn data of 1998 confirms the broad occurrence of fine sand offshore. The RoxAnn system does not distinguish the slight coarsening in the central offshore lobe of 


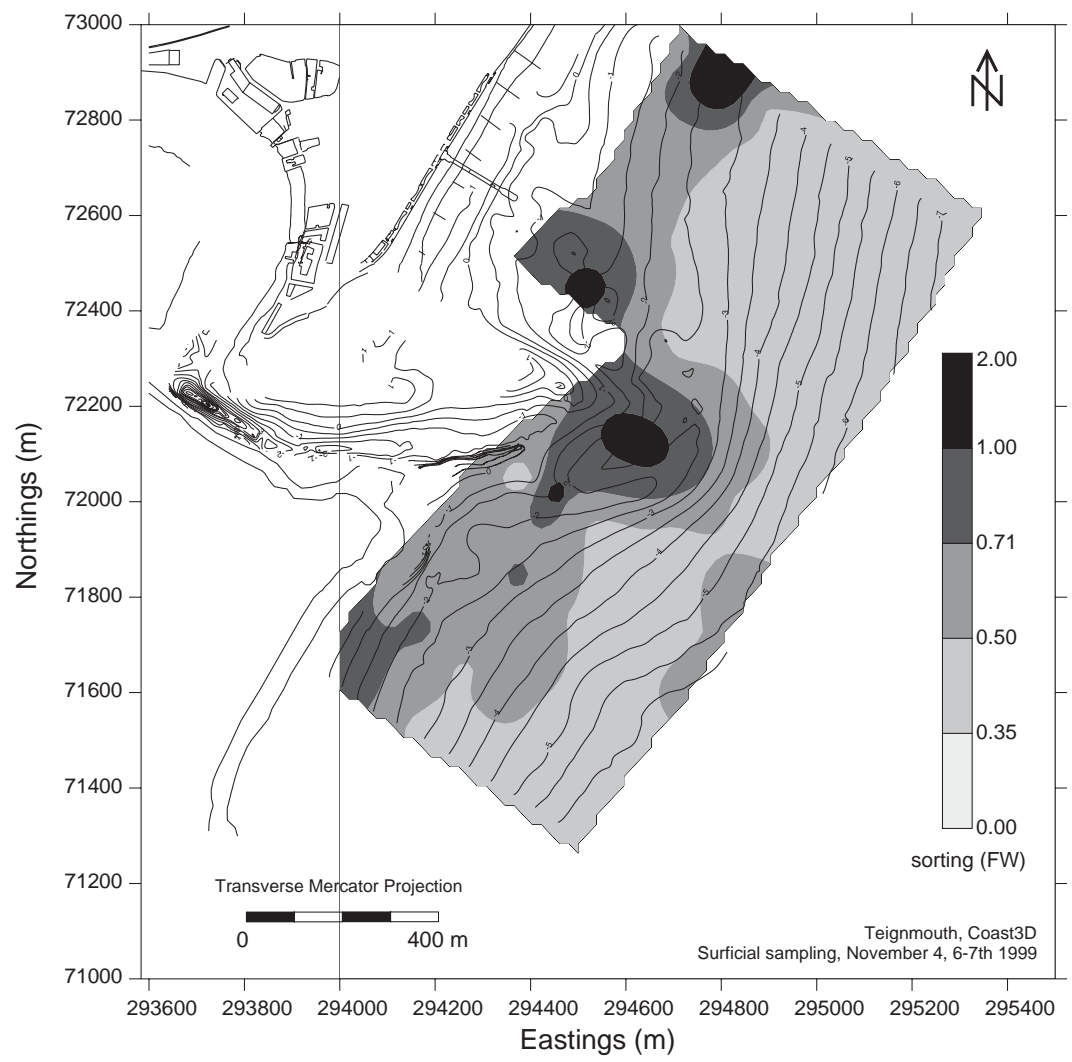

Fig. 7. Contour plot of the areal distribution of the sorting values (Folk and Ward ,1957) of the surficial sediments (0-0.35 phi: verywell sorted; $0.35-0.50$ phi: well-sorted; $0.50-0.71$ phi: moderately well-sorted; $0.71-1.00$ phi: moderately sorted; $1.00-2.00$ phi: poorly sorted).

the ebb tidal delta. The results do show that there is a coarsening of the bed material in the area of the shallow intertidal banks and inshore from about $-1 \mathrm{~m}$ depth contour at the beach to the north of the pier. However, changes in morphology over the study period in the area of the nearshore banks was associated with shifts in the detailed sediment-type distribution.

\subsection{Sediment trend analysis}

Using the sediment trend analysis procedure of Gao and Collins (1992), residual transport directions have been calculated on the basis of the areal distribution of the mean, sorting and skewness of the surficial sediments (Fig. 9). The methodology is based on the assumption that in the direction of transport, the sediments become finer, better sorted with a more negative skewness or coarser, better sorted with a more positive skewness. According to Gao and Collins (1994), it is the combined trend of the two cases that is indicative of residual sediment transport. This approach has proven its efficiency in a variety of environments and was fully tested on the surficial sediments of a marine sandbank on the Belgian continental shelf (Gao et al., 1994). The method used for the calculations is outlined in Gao (1996). It should be noted that the thickness of the arrows is a measure of significance, not of the strength (Gao, 1996).

The sedimentological parameters calculated according to Folk and Ward (1957) were chosen as input values for the sediment trend analysis. A critical distance of $250 \mathrm{~m}$ was selected, meaning that every sample is compared with its neighbours up to a $250 \mathrm{~m}$ distance. 

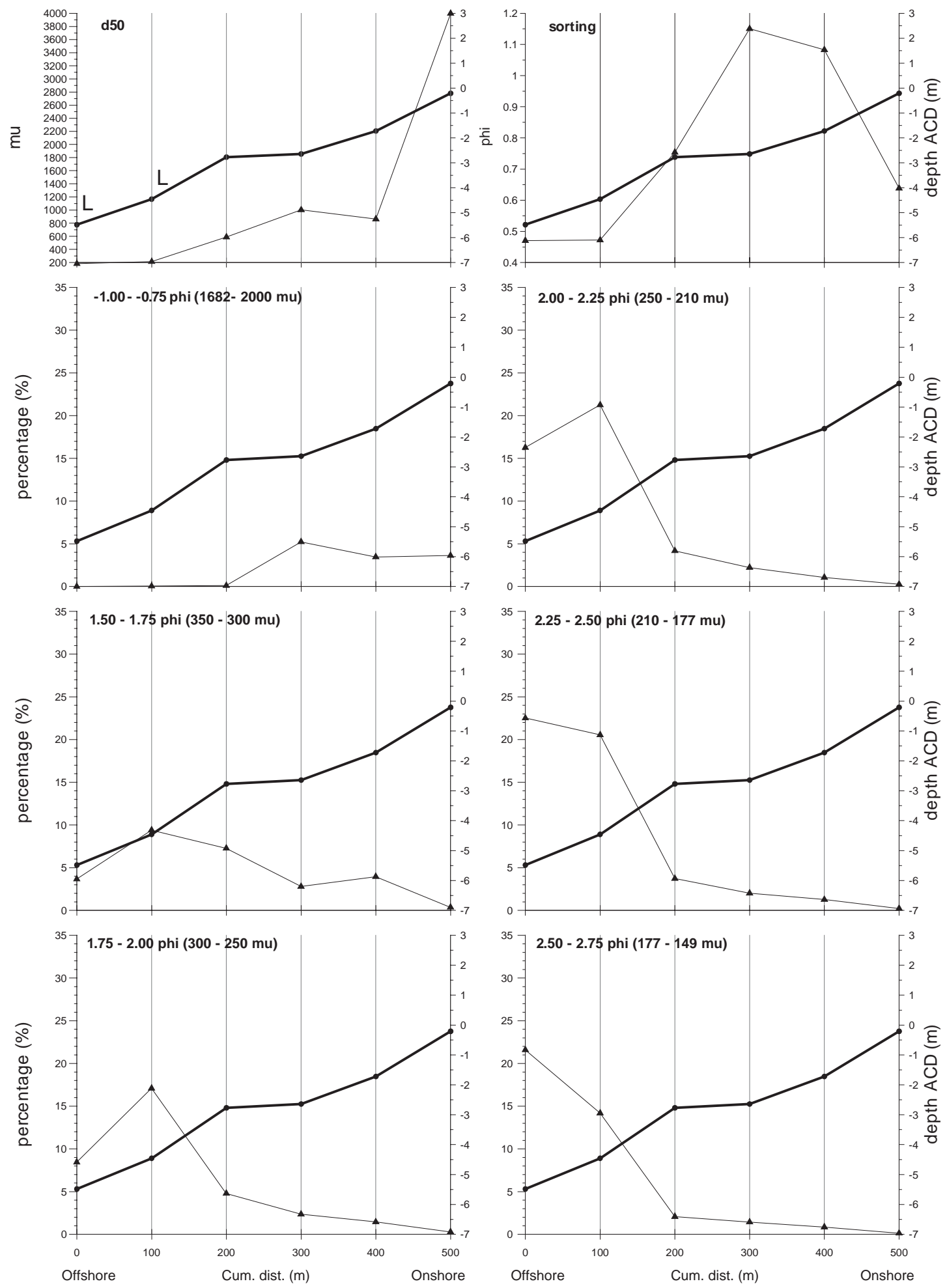


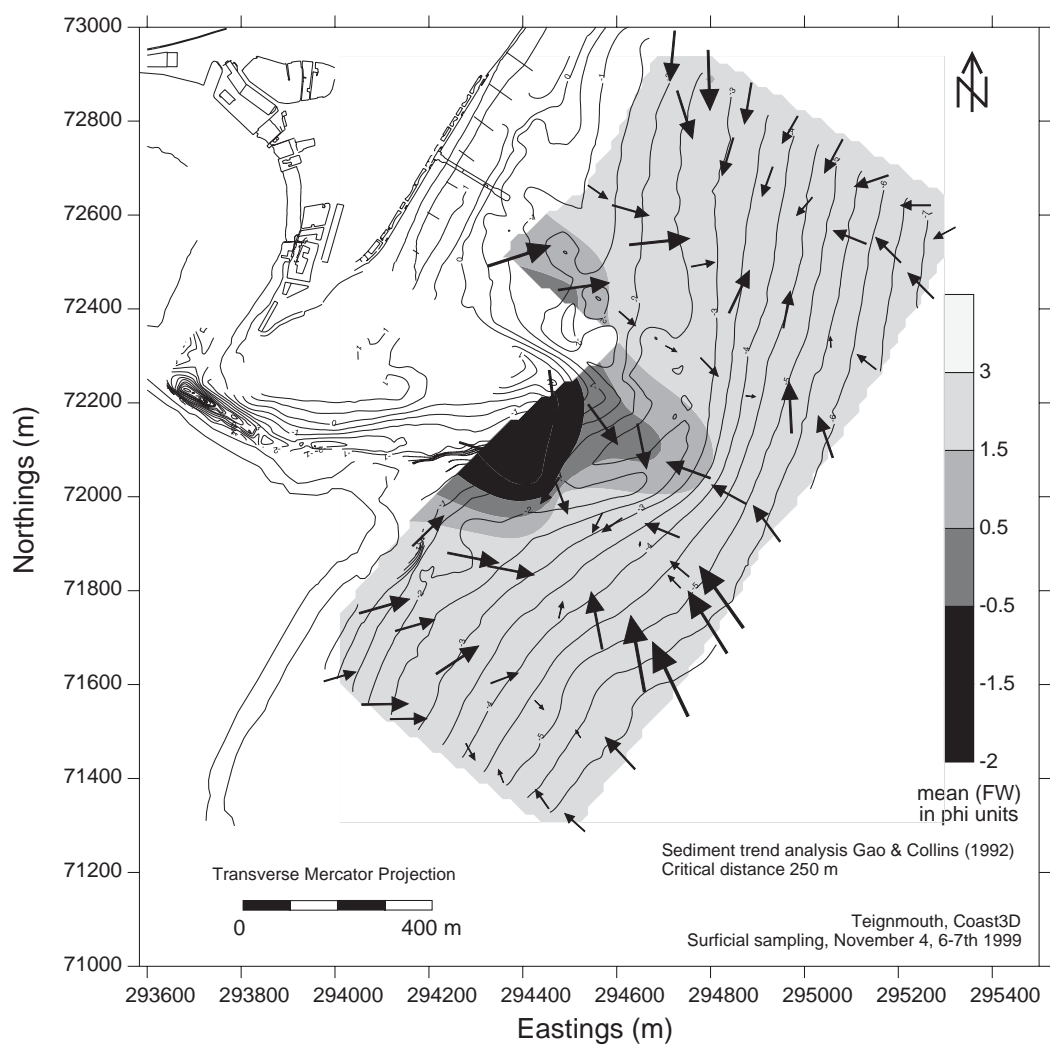

Fig. 9. Sediment trend analysis using the Gao and Collins (1992) approach. The thickness of the arrows represents the significance of the result at each location.

The application of the method results in a fairly consistent transport pattern and allows to delineate zones linked to different physical processes (Fig. 9). The thickness of the arrows represents the significance of the result at that location. As was expected from the general sedimentological findings, a significant transport pattern is seen from the lobes in an offshore direction. To the northeast, the vectors clearly point to the southwest. However, south of the estuary, the vectors point in an opposite way. Interestingly, are the highly significant transport vectors in the southeast of the study area from an offshore direction. A convergent residual transport pattern is seen north and south of the ebb tidal delta whereby the vectors from the east tend to be more significant. Also of interest are the opposing transport vectors along the central lobe with a convergence of the vectors halfway. Apparently, this location corresponds with the limit of coarse-grained ripples within the ebb tidal delta.

\section{Morphology}

\subsection{Beach morphology and classification}

In order to characterise the beach and quantify its morphodynamic features, sediment sampling, beach profiling and measurements of the incident

Fig. 8. Cross-shore profile (thick line) representing the median diameter and sorting of the surficial sediments and a fraction analysis from -1.0 to -0.75 phi $(1682-2000 \mu \mathrm{m})$ and from 1.5 to 2.75 phi $(350-149 \mu \mathrm{m})$ (thin lines). Depth referenced to $\mathrm{m} \mathrm{ACD} \mathrm{(thick} \mathrm{line).} \mathrm{'} \mathrm{L}$ ' indicates the presence of the tubeworm Lanice conchilega. 
wave climate were carried out by the University of Plymouth.

In a longshore position just south of the pier (location, see Fig. 3), a transect was identified that typified the profile of the beach and was termed the 'north transect'. Surveys were carried out to establish the beach profile, and sediment samples were taken at representative points on the profile. Wave heights and periods were obtained on this transect from a pressure sensor and data logger situated half way up the upper beach.

It should be mentioned that the classification applies to the beach north of the estuary mouth. Measurements have indicated that this beach is reasonably independent of the estuary mouth bar system and also Robinson (1975) indicated that the bar system is a self-contained unit with little being added from the coast to the north. Hence, the beach classifications, originally developed for 2D coasts, only apply for the region north of the horseshoe bank, past the pier and further north.

In order to classify the beach morphology, the surf similarity parameter of Guza and Inman (1975) was used:

$\mathrm{SSP}=\frac{H_{\mathrm{b}}(2 \pi / T)^{2}}{g \tan ^{2} \beta}$

(SSP $>20 \Rightarrow$ dissipative; $2.5<\mathrm{SSP}<20 \Rightarrow$ intermediate; $S S P<2.5 \Rightarrow$ reflective).

Wave heights $\left(H_{\mathrm{b}}\right)$ and periods $(T)$ were identified from the pressure sensor located in the intertidal region along the north transect (for location, see Fig. 5). The beach slope $(\tan \beta)$ was identified from the profile surveys.

The wave height at the breakpoint $\left(H_{\mathrm{b}}\right)$ was determined by taking the highest wave height in each tidal record from the SLOTs. The wave heights are the gravity band $H 1 / 3$ wave heights calculated in the standard manner from the COAST3D database. The $H_{\mathrm{b}}$ estimates are based on measurements on the upper beach. The method does not allow for any difference in breaker height between the wave height on the steep upper beach and the low-tide terrace. It only works if the instruments are outside the surf zone. This is a reasonable assumption because of the steepness of the beach.
The method works because the waves shoal up to the breakpoint, after which they break, and reduce in height. Since the instruments are flooded as the tide rises, they sample increasing wave heights through the surf, maximum wave heights through the breakpoint, and a reduction of wave height in deeper water outside the surf zone.

The morphology of the beach is closely related to wave breaking, and this was assessed using the inshore parameter of Galvin (1968):

$B=\frac{H_{\mathrm{b}}}{g T^{2} \tan \beta}$

( $B<0.003$, surging; $0.003<B<0.068$, plunging; $B>0.068$, spilling).

Further to this, the parameter of Masselink and Short (1993) was applied to indicate the importance of the tidal range relative to the wave height. In Masselink and Short's classification system, the relative tidal range (RTR) is used in conjunction with a dimensionless fall velocity $(\Omega)$ to parameterise the beach state, in which

$\mathrm{RTR}=\frac{\mathrm{TR}}{H_{\mathrm{b}}}$,

$\Omega=\frac{H_{\mathrm{b}}}{w_{\mathrm{s}} T}$,

where TR is the tide range, and $w_{\mathrm{s}}$ is the sediment fall velocity. Sediment fall velocity was calculated from the grain diameter using Soulsby's equation (Soulsby, 1997).

The morphology of the intertidal zone can be divided into two parts. The northern part is a rectilinear beach with a flat low-tide terrace $(\tan \beta=0.01)$ and a steep, narrow upper beach ( $\tan \beta=0.11)$ (Fig. 5). The low-tide terrace extends approximately up to MSL (Miles et al., 2000), and has often a shallow bar and a runnel located onshoreward. Ripples were often present in the trough of the shallow bar on the low-tide terrace, with typical wavelengths of $12-13 \mathrm{~cm}$, and heights of $2-3 \mathrm{~cm}$. Fig. 10 shows the most important morphological entities.

Towards the south, the intertidal area is closely related to the estuary mouth. The upper beach is slightly narrower than that to the north. In contrast, the lower beach is very wide with several intertidal bars and shoals. The main bank, called 


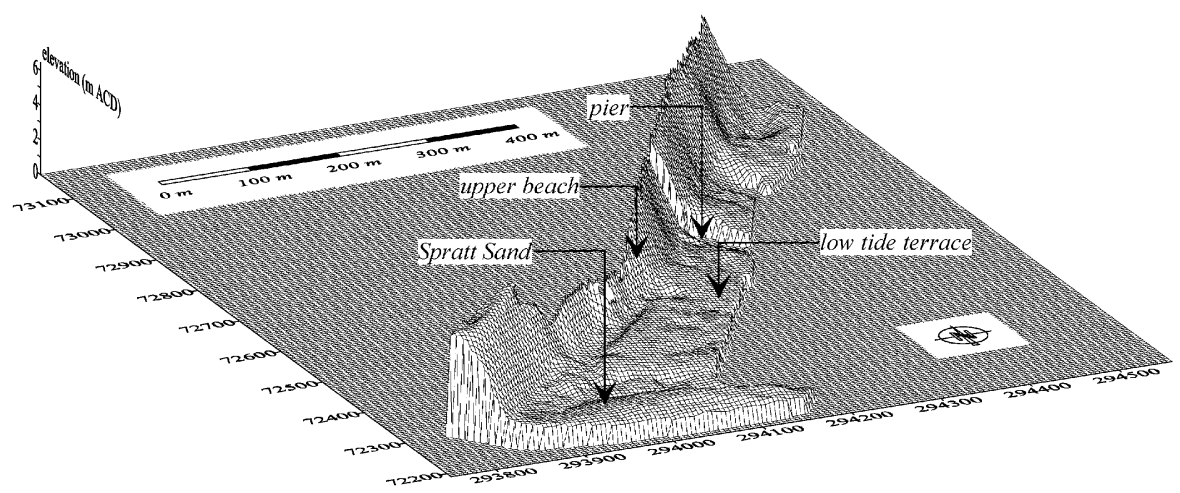

Fig. 10. Beach morphology from the DGPS survey at the end of the experiment (23-25, November 1999).

the 'Spratt Sand', is located along the inner channel bend of the inlet. The 'Spratt Sand' is, at a local scale, characterised by migrating ripples and dunes in response to the alternating flood and ebb currents. The 'Spratt Sand' fully emerges only during spring tide. The 'East Pole' bank, located about $200 \mathrm{~m}$ northward of the 'Spratt Sand', with an orientation normal to the coastline, was identified during the pilot campaign in Teignmouth in March 1999. The location of this bank has been discussed by Robinson (1975) showing a cyclic movement with a period of about $3-5$ years. During the main campaign, in October, this bank was not connected to the beach and sometimes emerged during high spring tides.

In order to classify the morphology of the beach, wave data have been recorded along the north transect (Fig. 3). Significant wave heights and wave periods at the breakpoint were calculated from the data for 35 tides during the main experiment. Wave heights at the breakpoint varied during the Teignmouth main campaign from 0.2 to $1.4 \mathrm{~m}$. Wave periods measured varied between 4 and $20 \mathrm{~s}$. In order to establish a modal wave height and period, histograms of the breakpoint wave heights and periods from each tide were calculated, with bin widths of $0.1 \mathrm{~m}$ and $1 \mathrm{~s}$, respectively. The modal wave height was $0.4 \mathrm{~m}$, and the modal wave period was 6 s. Fig. 11 gives a histogram of wave heights and periods measured at the breakpoint on the upper beach during the main campaign.

The wave parameters together with the values of the beach slope enabled the calculation of the surf similarity parameter (SSP). Modal conditions on the upper beach give an SSP value of 1.85 , while the lower beach has an SSP value of 276. The classification of Guza and Inman (1975) therefore indicates that the upper beach is morphodynamically reflective, while the lower beach is dissipative.

The parameter of Galvin (1968) indicates that modal conditions were suitable for plunging waves to be predominant on the upper beach $(B=0.01)$, while spilling breakers dominate the lower beach $(B=0.12)$. Visual observations at the site substantiate these calculations. The tidal nature of the beach is such that the conditions in the surf zone will vary during the tide. While the tide is low, waves encounter the flat part of the beach, and break as spilling waves on a dissipative beach. However, when the tide rises, waves shoal over the low-tide terrace, and break as plungers in a narrow surf zone on the steep beach.

When wave height is particularly high, or when the water just covers the low-tide terrace, waves start to spill on the low-tide terrace, traverse an essentially dissipative zone, before plunging on the steeper upper beach. As this upper beach is reflective, this can lead to the outgoing wave energy interacting with the incoming waves, and setting up a spectacular clapotis/standing wave system. The most explosive clapotises only form when waves break (spilling) on the low-tide terrace, and the tide is sufficiently high for the waves to reflect from the base of the steeper upper beach. 

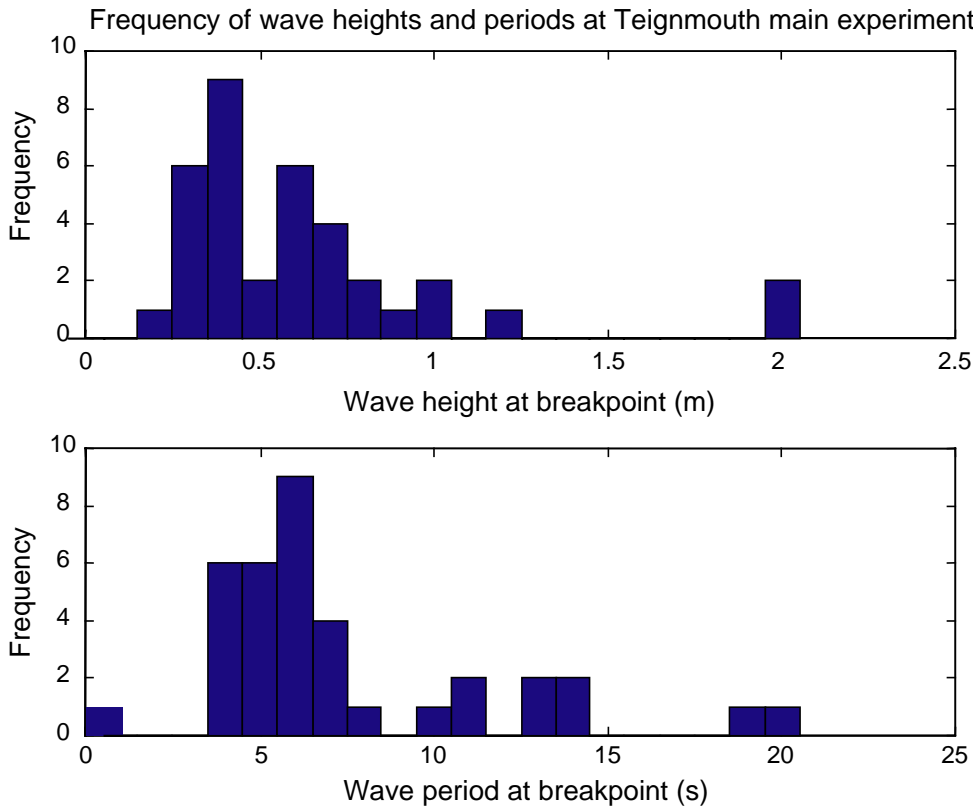

Fig. 11. Histogram of wave heights and periods measured at the breakpoint on the upper beach during the main campaign.

The effect of tide range on Teignmouth's beach shape is indicated by the parameterisation of Masselink and Short (1993). The mean spring tidal range at Teignmouth is $4.2 \mathrm{~m}$, and the modal wave height of $0.4 \mathrm{~m}$ therefore gives a relative tidal range of 10.5. The sediment fall velocity, calculated from the grain diameter using the equation of Soulsby $(1997)$ was $0.122 \mathrm{~m} / \mathrm{s}\left(d_{50}=1100 \mu \mathrm{m}\right)$ on the upper beach and $0.029 \mathrm{~m} / \mathrm{s}\left(d_{50}=250 \mu \mathrm{m}\right)$ on the lower beach. Masselink and Short's dimensionless fall velocity was therefore 0.55 for the upper beach, and 2.32 for the lower beach. When the coarser upper beach grain-size is used in this parameterisation, the beach category is correctly identified as a low-tide terrace, reflective beach. The finer grain-size of the low-tide terrace puts the classification just into an intermediate and 'ultradissipative' category, although the beach profile does not resemble this shape. The parameterisation therefore indicates that for the given incident wave conditions and dimensionless fall velocity on the upper beach, the large tidal range has the effect of reducing bar formation in the region of the lowtide terrace, reducing the likelihood of rip currents, and reducing the likelihood of cusp formation.

\subsection{Ripples and dunes at 'Spratt Sand'}

The dimensions of ripples and dunes of the intertidal shoal 'Spratt Sand' were measured with the ASRP and have been analysed with the DT2D dune-tracking software (Wesseling, 1999). The analysis provides information on dune height, length, shape and migration rates (see also Hoekstra et al., 2004). 'Spratt Sand' (Figs. 2 and 3 ) is more or less stable within the otherwise highly mobile and dynamic environment that is characterised by cyclic morphological changes with a period of 3-5 years (Robinson, 1975). 2D and $3 \mathrm{D}$ ripples and dunes commonly develop in this sandy top layer and either migrate in an onshore or offshore direction. 'Spratt Sand' is characterised by water depths of -1 to $-2 \mathrm{~m}$ ACD.

The time-dependent character of ripple and dune dimensions on 'Spratt Sand' is illustrated in Fig. 12. The average ripple dimensions are represented by a black dot; indicated is also the value of \pm 1 sigma (standard deviation).

The ripple or dune height generally varies between a few $\mathrm{cms}$ and a maximum of $18-20 \mathrm{~cm}$, 

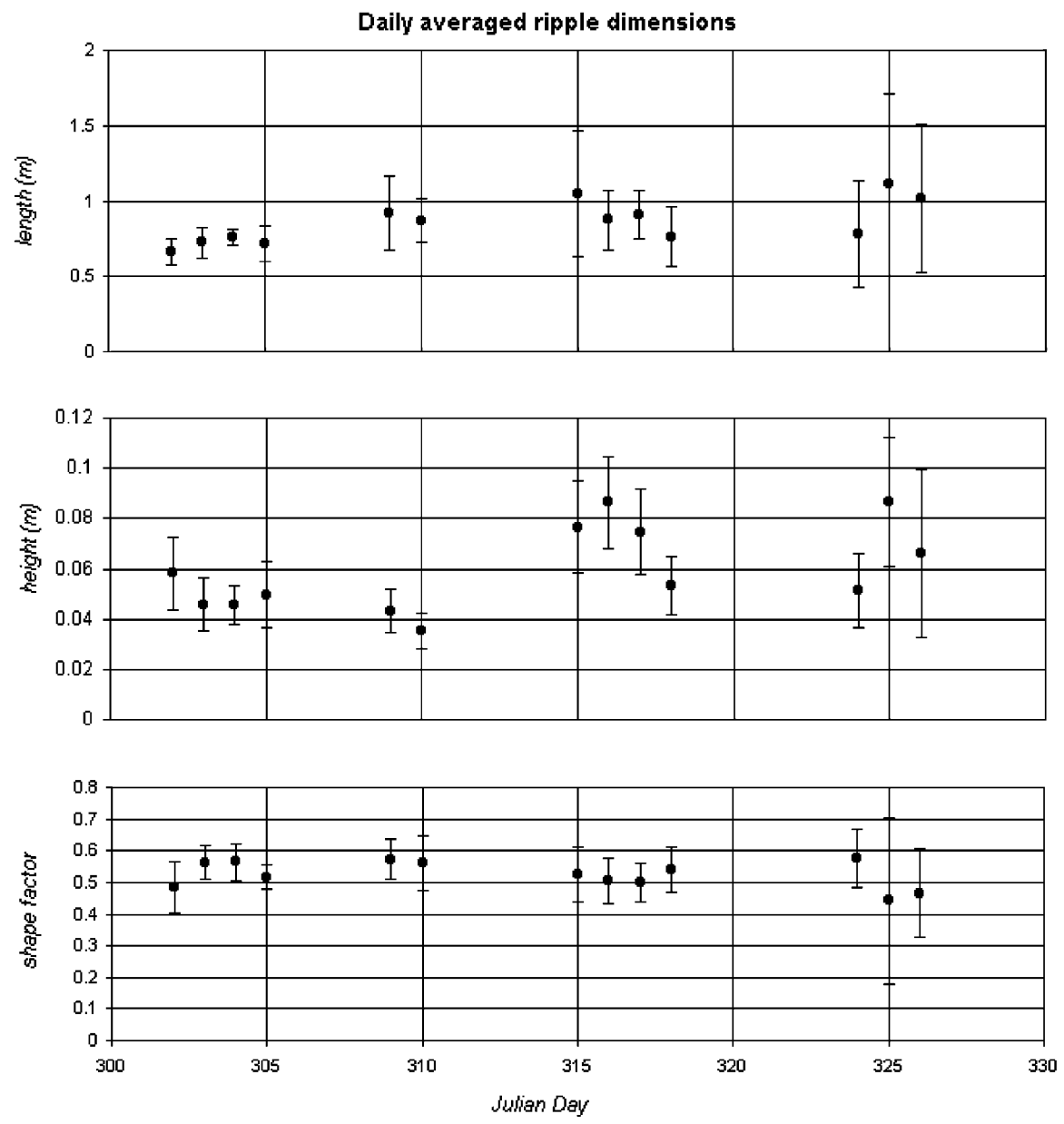

Fig. 12. Daily averaged ripple dimensions. The average ripple dimensions are represented by a black dot; indicated is also the value of \pm 1 sigma (standard deviation).

whereas the dune length varies accordingly between about 0.5 and $2 \mathrm{~m}$.

The shape factor is determined through the formula $A /(H L)$ with $A$ being the surface view of the bedform; $H$ its height and $L$ its length. A value of 0.5 is obtained for perfect triangular ripples; most common is a value of 0.6. At High Water slack, the calculated shape factor was often less than 0.5 due to the software programme that takes the trough exactly between the crests of the ripples that are strongly symmetrical at that time. In reality, there is a plane bed between the ripples that should not be taken into account and this results in a ripple that is much smaller than the triangle created by the software programme.

The planform of these bedforms is commonly $2.5-3 \mathrm{D}$ in shape with a weakly undulatory, linguoid or lunate shape. The shape and orientation of these ripples and dunes rapidly reverses at high water slack and ebb-dominated bedforms replace flood-dominated bedforms generated during the first part of the flood-ebb cycle (Fig. 13).

Sediment availability appears to be a crucial factor for the existence and dimensions of bedforms. As demonstrated by Hoekstra et al. (this volume; Fig. 7) the presence of (fully) developed dunes not only depends on flow conditions (flow 
Ripple patterns on Day 305 (1-1-1999)
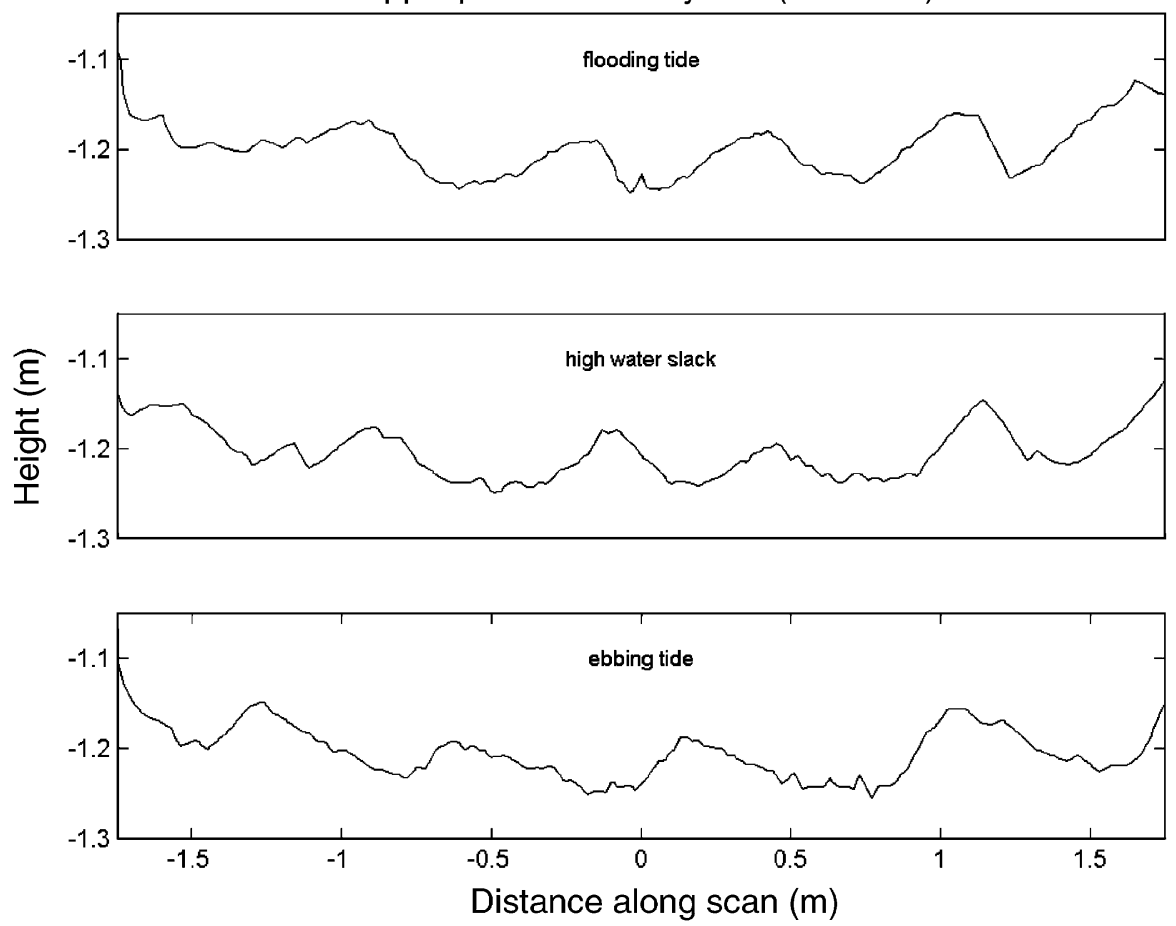

Fig. 13. Ripple patterns showing the variation in ripple morphology from the flooding tide over the period of high water slack to the ebbing tide. In the upper panel, the flood is from left to right; the middle panel shows high water slack with almost no current (and in the lower panel, the ebb is from right to left).

velocity and water depth) but is also strongly correlated to the presence of sand. The 'Spratt Sand' only has a thin veneer of sandy and gravelly deposits (thickness of $10-30 \mathrm{~cm}$ ) on top of a rocky and non-erodable substratum. Occasionally (and periodically?), the shoal is stripped of sediment and a layer of about $20 \mathrm{~cm}$ of sediment is removed from the shoal. This process largely prevents the further growth and development of ripples and dunes. As a result, ripple height in these conditions is typically in the order of $0.04-0.06 \mathrm{~m}$ (Julian Day 302, 29 October 1999) or 0.03-0.09 m (Julian Day 305, 01 November 1999; pre-storm; Fig. 12). For conditions with a sufficient supply of sediment the (ripple) height may grow from an initial value - at low current velocities - of about 0.02 $0.03 \mathrm{~m}$ for small-scale ripples to $0.16-0.18 \mathrm{~m}$ for dunes and at high current velocities (Julian Day 326, 22 November 1999; post-storm conditions, Fig. 12).

\subsection{Nearshore morphology}

The large-scale morphology of Teignmouth area has mainly been described in Section 2.1 and is represented in Fig. 3. From the detailed bathymetric surveys that were carried out within COAST3D, digital terrain models (DTM) were created and were used to study the morphological changes.

Fig. 14 is a DTM based on the data of $27-28$ October 1999 and illustrates the river Teign as it meets the open coastline, the sand spits and offshore bars. Noticeable is the offshore limit of the ebb tidal delta that has a bar-like appearance.

The spatial extent of the small-scale morphology was investigated by means of rectified very-high resolution side-scan sonar mosaicing. As was pointed out in Section 3.6, two mosaics of the Teignmouth area were produced based on observations on 4-5 November and one on 18 


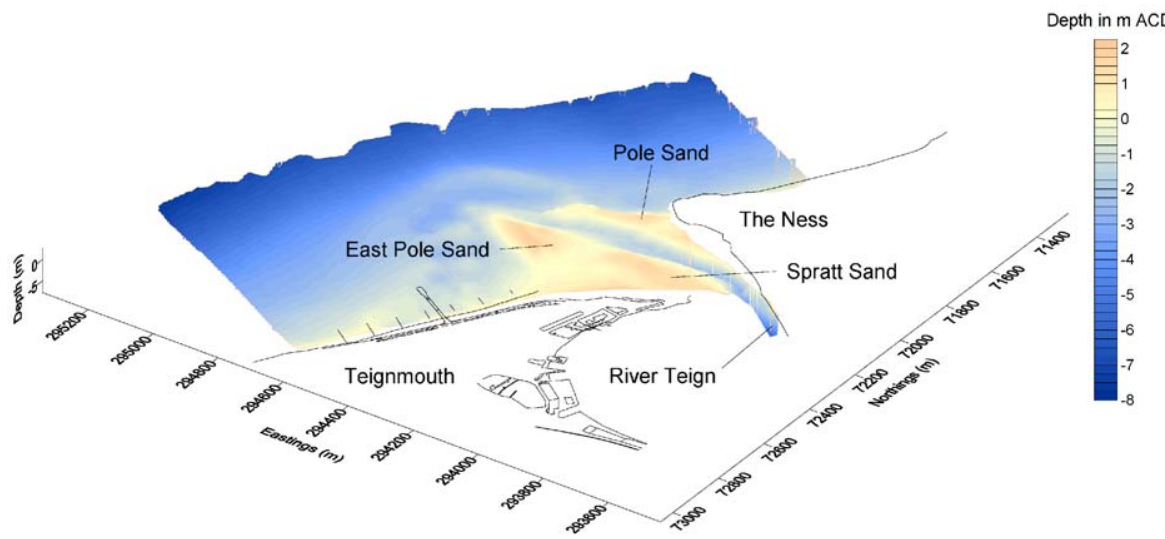

Fig. 14. A $3 \mathrm{D}$ view diagram of the beach morphology for the whole area including the estuary channel, the banks and the offshore area-looking from inland.

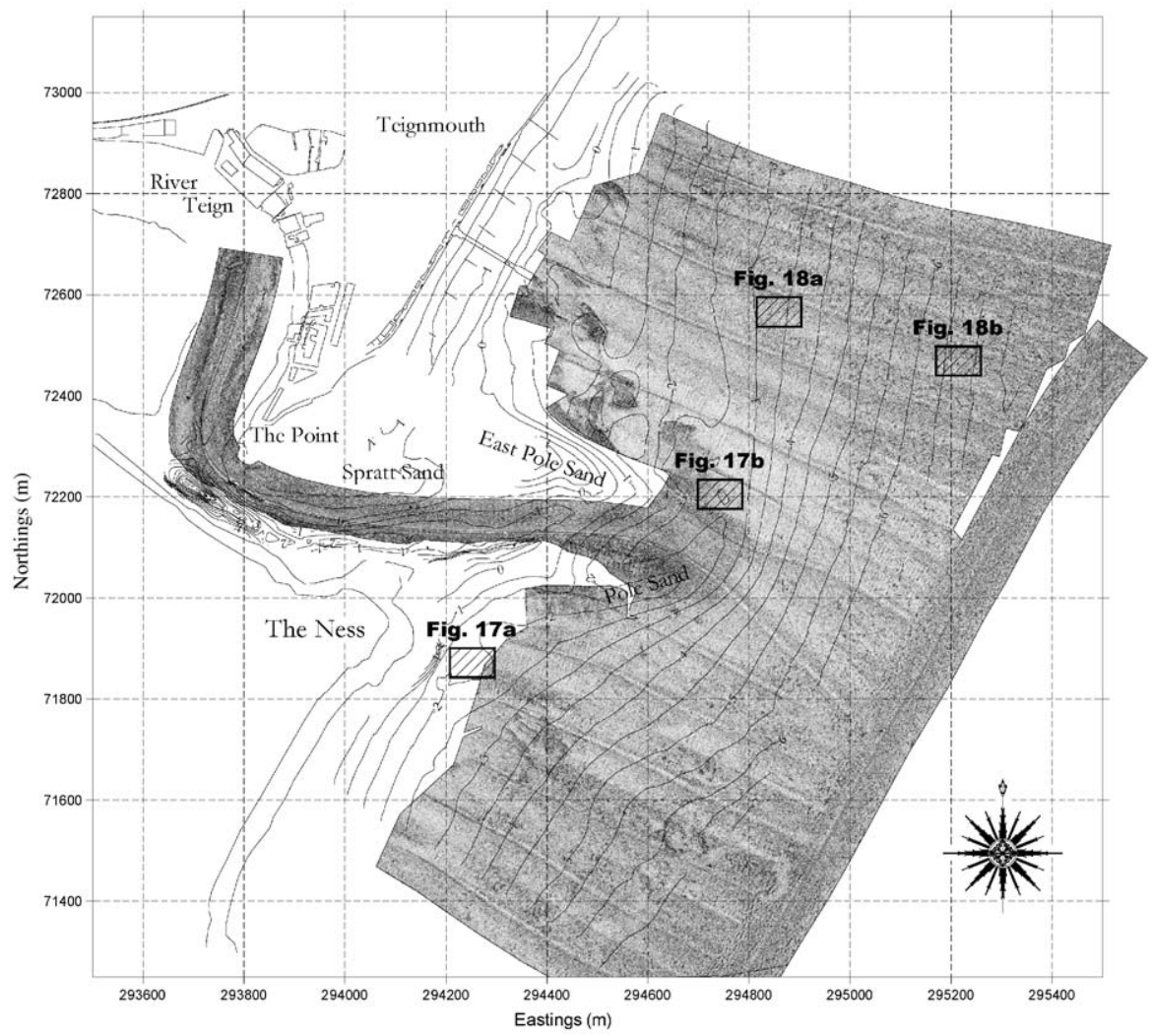

Fig. 15. Composite map of the side-scan sonar imagery (4-5/11/1999) and the bathymetry (6-8/11/1999) (True chart dimensions $2000 \times 900 \mathrm{~mm}^{2}$, processed at a resolution of $10 \mathrm{~cm}$ ). The frames give the position of the side-scan sonar images displayed in Figs. 17 and 18 . 
November. As the sediment samples were taken in the period 4-7 November, the first side-scan sonar imagery is mainly described below. Fig. 15 shows the side-scan sonar mosaic of 4-5 November superimposed with the bathymetry of 6-8 November. The interpretation is based on differences in reflectivity and provides as well information on the small-scale morphology as on the intrinsic nature of the seafloor.

The areal distribution of the different acoustic facies is schematically represented in Fig. 16 (data of 4-5 November). It primarily reflects four distinctive zones.

A first zonation corresponds with the areal extent of the ebb tidal delta (zone A). The acoustic reflectivity is high as it represents a coarse-grained rippled seafloor. The asymmetry of the ripples to megaripples is hard to distinguish and also their strike is not straightforward and varies from coast oblique to somewhat cross-shore. Although rather restricted, the imagery shows eastward pointing lunate megaripples in the central lobe of the estuary mouth (indicated by the central darkest area in Fig. 16). The crestline of lunate megaripples close upcurrent meaning that the spurs point in the direction of sediment transport (Allen, 1968). As was outlined in Section 2.1, the distal end of the ebb tidal shoal is dredged on a more or less daily basis. An example of the scrape marks and associated deposits are shown in Fig. 17a. Along East Pole Sand, towards the 'Spratt Sand' area and towards the beach, the side-scan sonar

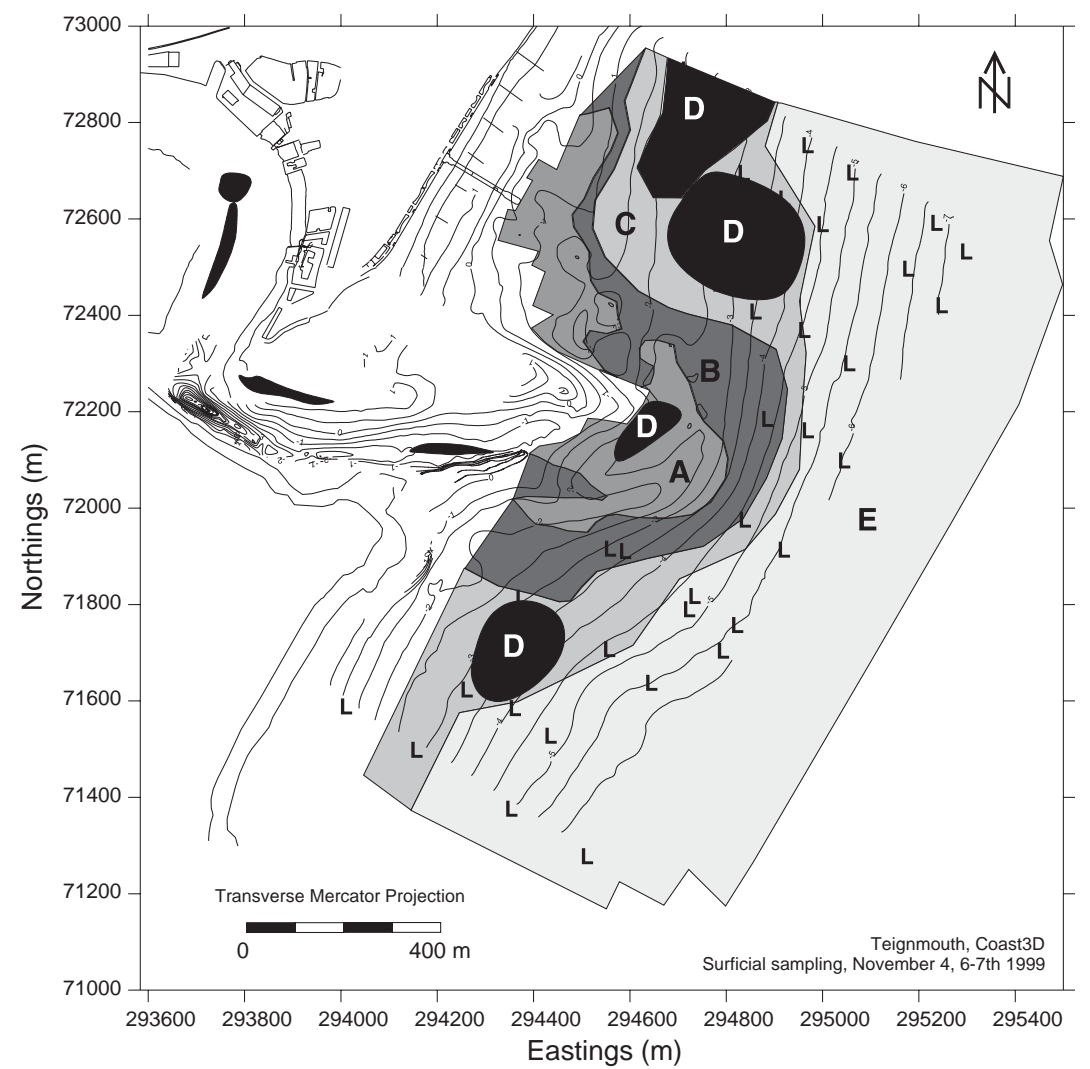

Fig. 16. Interpreted areal distribution of the different acoustic facies in the estuary-nearshore area derived from side-scan sonar observations on 4-5 November 1999. Zone A corresponds with the zones where coarse-grained ripples to megaripples are present. The surrounding zones are generally devoid of bedforms (zone B). However, zones D is representative of a higher dynamics witnessed by megaripples to sandwaves. The outer zone E corresponds with the area having a patchiness nature. 'L' corresponds with the polychaete Lanice conchilega as found in the samples. 


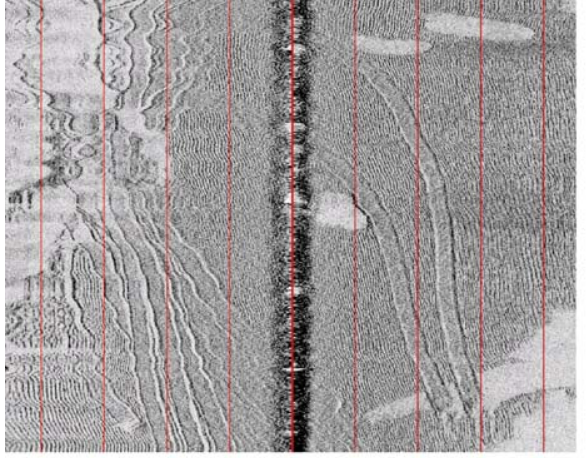

(a)

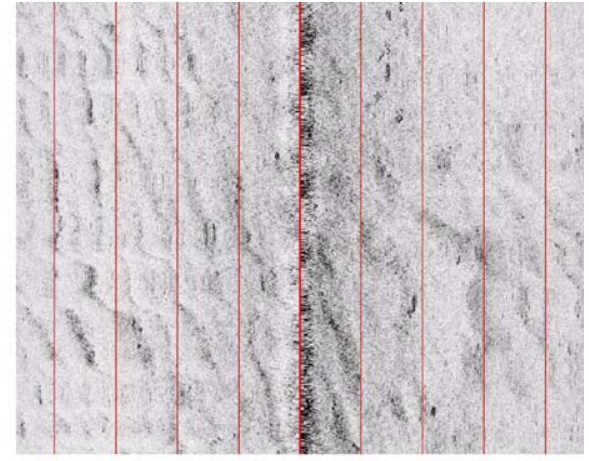

(b)

Fig. 17. (a) Rectified side-scan sonar image showing the dredging activities at the distal end of the ebb tidal delta. The lines represent the traces of the plough dredger; sand is being scraped from the surface and left behind at the end of the dredged line where it forms a heap corresponding to a white (unconsolidated) patch on the sonar image. (b) Rectified side-scan sonar image witnessing the bedform pattern (scale line spacing of $10 \mathrm{~m}$ ).

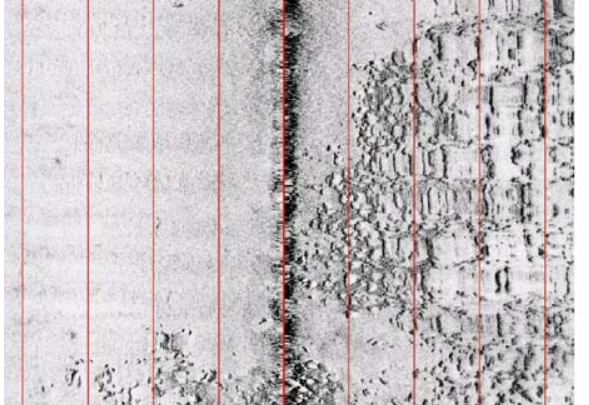

(a)

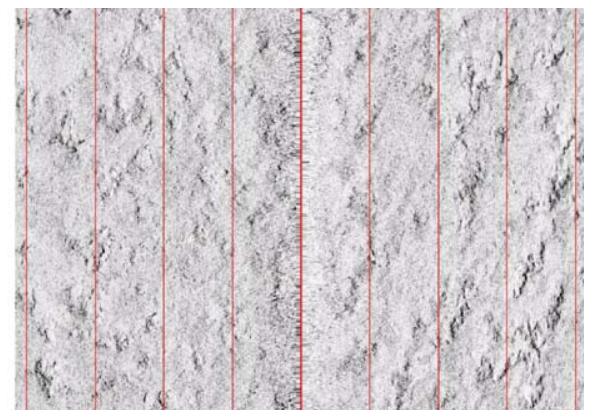

(b)

Fig. 18. (a) Rectified side-scan sonar image showing the rock outcrops near 'The Ness' and the homogeneous texture around it. (b) Rectified side-scan sonar image of the patchiness nature of the area offshore the estuary mouth (scale line spacing of $10 \mathrm{~m}$ ).

imagery indicates the presence of high reflective coast oblique megaripples (Fig. 17b). The coarsegrained ripples are mostly overlain with a veneer of fine sands. Interestingly, the side-scan sonar mosaic of 18 November, showed very clear crossshore-oriented ripples in the central lobe, albeit no lunate megaripples were observed. The latter imagery also shows another zone of higher reflectivity associated with the extent of the rocky area off 'The Ness' (Fig. 18a).

Around the rippled areas, a distinctive zone of lighter reflectivity is present. This region is devoid of bedforms and is associated with a finer sediment texture (zone B).

Further offshore, the acoustic facies remains fairly light in reflectivity, though regions of bed- form occurrences are present (zone C) (darkest areas in Fig. 16). The side-scan sonar imagery shows the presence of faint cross-shore-oriented bedforms (zones D).

The patchiness that dominates the nearshore area around the estuary mouth is most peculiar (zone E) (Fig. 18b). Although, the acoustic facies resembles the presence of gravelly deposits, all of the samples consisted of fine well-sorted sands. Possibly, the imagery reflects an abrasion platform overlain with fine sandy sediments. Information on sediment thickness is given by the published seabed sediments chart for this area (BGS, 1983). This chart is combined with an inset map on a scale of 1:1000000 showing a sediment thickness of $1-5 \mathrm{~m}$ along the whole frontage of Teignmouth. 
Also given, but imprecisely at that scale, is the presence of a submerged cliff line running parallel to the coast (within $1 \mathrm{~km}$ of the coast) both north and south of the location of the estuary ebb shoal (Whitehouse et al., 2000). However, the imagery might also be influenced by the presence of dense fields of tube worms (possibly Lanice conchilega). This faunal assemblage is known to have a characteristic acoustic fingerprint as the colonies have a high capacity to trap suspended sediments forming an irregular surface. A similar texture was found off the Cherbourg Peninsula by Berne et al. (1988) and recently by Degraer et al. (2000) in the Belgian nearshore.

\section{Sediment dynamical behaviour of the intertidal and nearshore area}

\subsection{Beach evolution}

From the three topographic surveys that have been carried out at the beginning (25-27 October), at mid-time (8-10 November) and at the end (2325 November) of the experimentation period, sediment budgeting was performed to study the evolution of the beach. In accordance with the technique precision, zones with level variations less than $10 \mathrm{~cm}$ were excluded from this budgeting. The sediment loss observed during the first half of the experiment $\left(-600 \mathrm{~m}^{3}\right)$, the gain calculated for the second half $\left(+1150 \mathrm{~m}^{3}\right)$ and the net positive sediment budget for the 4 weeks of the campaign $\left(+550 \mathrm{~m}^{3}\right)$ are not significant as they are all included within the volumetric error margin. During the experiment period, the global sediment loss and gain are less noticeable than the displacements observed within the surveyed zone limits.

Beach evolutions on the low-tide terrace are weak. On the lower part of the beach, between the low water line (MLW) and the $-2 \mathrm{~m}$ ACD contour line, residual changes show mainly erosion of the sand bed, especially during the second part of the campaign. Residual erosion values mainly lie between 0.1 and $0.3 \mathrm{~m}$. The morphological development of Spratt Sand appeared to be quite stable. A weak accretion is observed on the main part of the intertidal shoal and some erosion areas are observed locally, at the toe of the beach, close to the channel and to the offshore extremity of the intertidal area. Between the beginning and the end of the campaign, maximum erosion, comprised between 0.25 and $0.5 \mathrm{~m}$, occurred on the upper beach, between the seawall base and the $-2 \mathrm{~m}$ ACD contour line (Fig. 19). But this erosion is not continuously observed and is interrupted by zones where accretion prevails. The volumetric evolutions on the upper and lower parts of the beach are both positive or negative during the same period. These results show that cross-shore sediment transport between the low-tide terrace and the upper beach are weak. The contrasted grain-sizes for each beach domain confirm the weakness of cross-shore sand movements.

The pattern of alternating erosion and accretion areas observed alongshore on the upper part of the beach, both northward and southward of the pier, is striking. Longshore beach profiles, located $30 \mathrm{~m}$ from the seawall base (Fig. 20), confirm this rhythmic alongshore behaviour. For each survey,

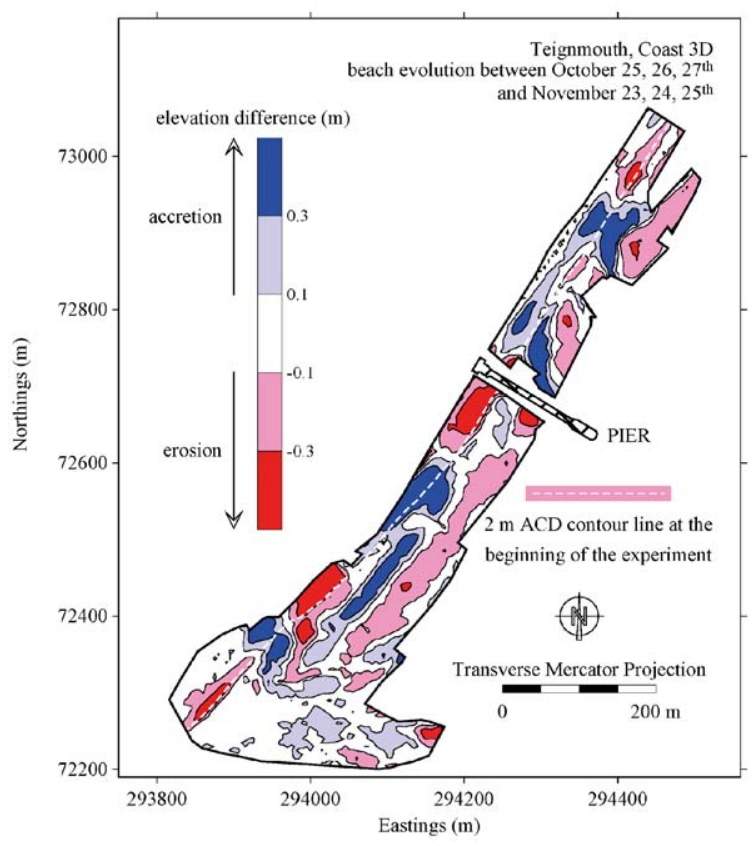

Fig. 19. Beach evolution during the experiments from DGPS surveys. The blank area in the middle of the beach transect is the GPS 'shadow zone' around the pier. 

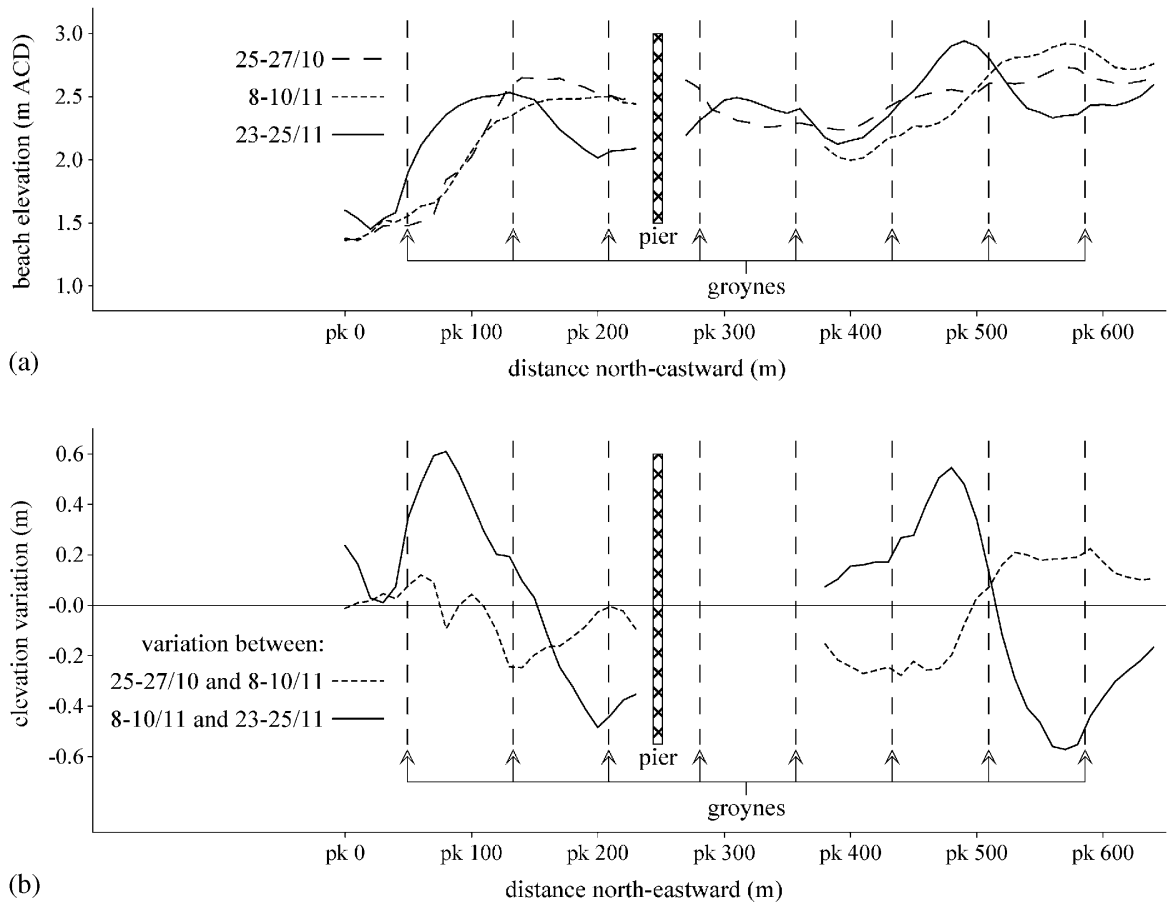

Fig. 20. Longshore beach profile $30 \mathrm{~m}$ from seawall base.

the mean longshore negative beach slope is oriented towards the estuary mouth. But this slope is not regular and two to four convex and concave areas alongshore located can be identified over the study zone. Opposite evolutions are observed (1) on both sides of the nodal points where variations are weak and (2) between the first and the second half of the experiment period.

It is thought that the upper beach behaviour is mainly driven by the longshore sediment transport induced by breaking waves. Miles et al. (2000) mentioned that the longshore wave induced current, and the sediment transport direction on the beach generally depends on the offshore wave direction. It reverses when the wave propagation passes through $140^{\circ}$, shore-normal at the beach being approximately $120^{\circ}$. During the second part of the experiment, the incoming direction, for waves with significant heights larger than $0.5 \mathrm{~m}$, observed $1 \mathrm{~km}$ offshore by the HR Wallingford waverider buoy, was $107^{\circ}$ probably inducing a southwestward current on the beach. A longshore southwestward migration of the two main convex areas (pk 580-480 and 180-80) is clear in Fig. 20a and is consistent with the wave direction. During the first half of the experiment period, the alongshore displacements of the convex or concave areas are more confused. The crest of the convex zone, located close to pk 100, and the concave area between pk 300 and 400 seem nevertheless to move northeastward. At that time, the mean incoming wave direction was $140^{\circ}$. The longshore sediment transport was probably weak, but oriented northeastward in accordance with the observed beach evolutions.

In conclusion, it appears likely that the reversal in alongshore sand movement and topographic features migration, observed during the campaign, is closely related to the contrasted longshore current direction.

\subsection{Evolution of the nearshore area}

The evolution of the nearshore area has been studied on the basis of chart differencing of the digital terrain models. Difference plots relative to 
survey 1 were made for surveys $2-4$ by subtracting the earlier bathymetry from the later. The differences between surveys 1 and 4 are shown in Fig. 21. Positive differences (green) represent accretion whereas negative differences (red) represent erosion.

The difference map primarily shows erosion of the outer end of East Pole Sand (in the region from 294300 to $294500 \mathrm{~m}$ east and from 72200 to $72400 \mathrm{~m}$ north). Moreover, a northwards movement of the bar running ENE from 'The Ness' was evident. The area just north of the end of the shipping channel shows erosion on the east flank of East Pole Sand and deposition on the NW flank merely corresponding with a transport from east to west. Erosion at the toe of the beach likely reflects waves from the E-NE quadrant. Unfortunately, the inshore part of East Pole Sand was not surveyed; hence, the direction of sand displacement is not evident to reveal.
There were bed level changes in the narrow estuary channel both seaward and landward of 'The Ness', and these are also shown in Fig. 21, but are less clear due to the small scale. They illustrate the highly dynamic nature of the inner study area and are not thought to be due to any storm event. The narrow estuary channel also has a dominant region of mobile sand with bedforms up to $0.5 \mathrm{~m}$ in height which may explain changes in the channel depths between surveys. The least depth selection routines in the data 'thinning' process (Section 3.3) may also have resolved the exit channel data to a shoaler value.

The major bed level differences between the different bathymetric surveys were likely caused by the strongest gale of the study period (NE Beaufort Force 6) which lasted 6 days in between surveys 2 and 3 (Whitehouse et al., 2000, Fig. 14). Significant wave heights easily reached more than $0.5 \mathrm{~m}$ with fairly constant wave periods and direction.

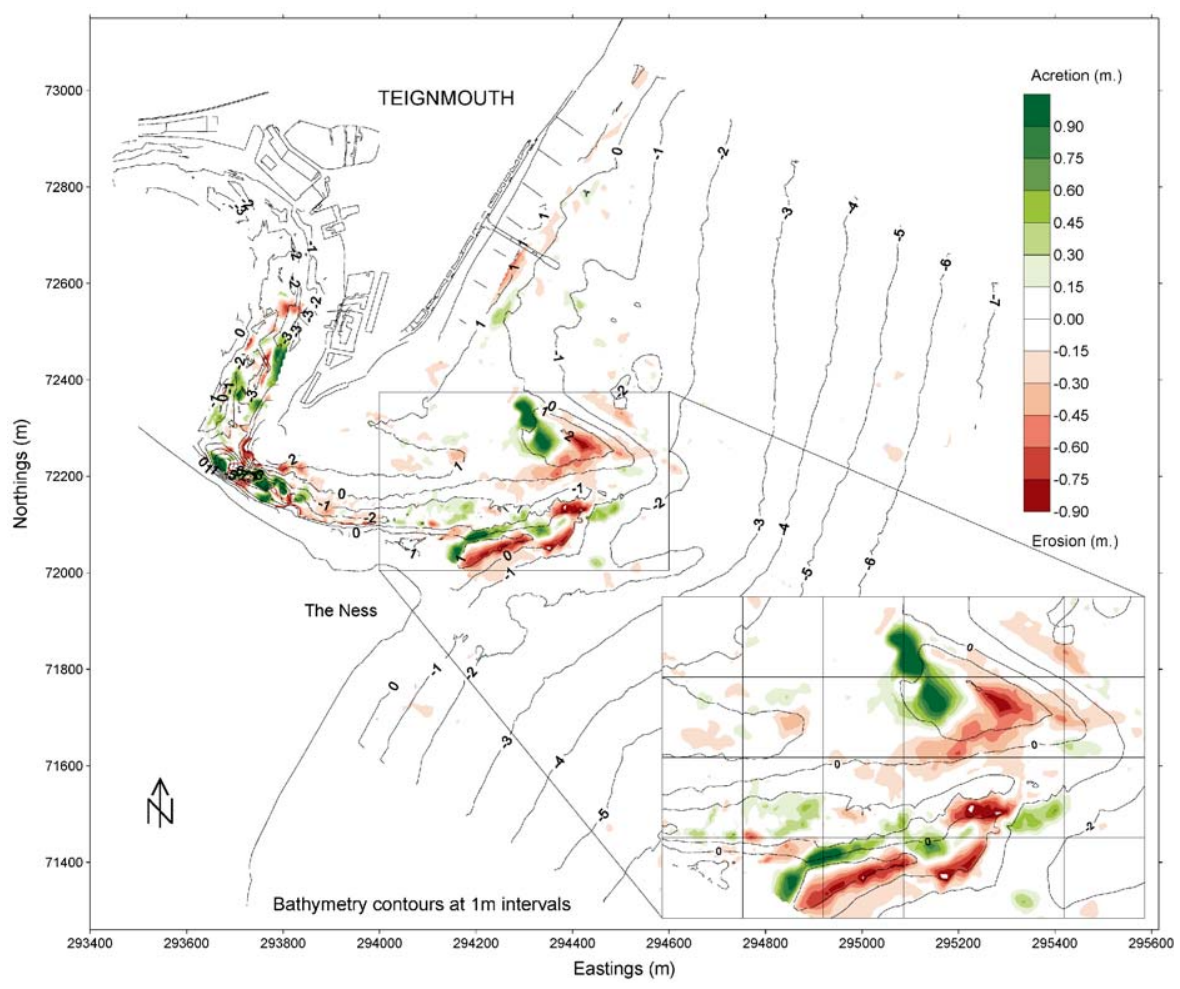

Fig. 21. An elevation difference plot showing elevation changes between 27-28/10/1999 and 24-25/11/1999 in the nearshore area. 


\subsection{Residual sediment transport pathways in the nearshore area: discussion}

Only few studies have described the small-scale morphology of the nearshore zone in relation to sediment transport pathways. This is mostly due to the difficulties implied by the measurement techniques and the rather restricted accessibility. Recently, a major contribution has been made by Osborne and Vincent (1993) and Thornton et al. (1998). The latter describe the DUCK94 experiments (North Carolina, USA) where side-scan sonar imagery was used to study the small-scale morphology, albeit in analogue format. During the COAST3D project, residual transport directions in the nearshore area of Egmond-aan-Zee have already been studied on the basis of digital side-scan sonar observations combined with surficial grab sampling (Van Lancker et al., 2001). This combination proved to be successful in terms of the understanding of the physical behaviour of nearshore systems and could be correlated with modelling results. Hence, the same approach was used along the estuary-nearshore system of Teignmouth.

Generally, sediment transport pathways can be derived from the strike and asymmetry of bedforms and hence side-scan sonar imagery appears to be a valuable tool. However, in most shallow water environments the bedform patterns tend to be more complex and generally no clear asymmetrical bedforms are observed. Still, the occurrence of bedforms is already a significant indication of sediment transport as it reflects an intense interaction of the seabed and the hydro-meteorological forces.

A superposition of the results of the sediment trend analysis vectors on the interpreted bedform map derived from side-scan sonar observations yields some interesting correlations (Fig. 22). It is seen that the hatched zones, indicative of the occurrence of bedforms, correspond with a convergence of significant transport vectors derived from a sediment trend analysis (Section 4.3). This could mean that in these areas, residual currents give rise to a sediment input and hence bedforms can be formed. From morpho- and sediment dynamical studies in the Belgian nearshore, it was clearly shown that indeed sediment availability is the constraining factor for bedform development regardless of the depth (Van Lancker and Jacobs, 2000; Van Lancker et al., 2000). In the offshore zone, the transport vectors tend not to be significant and side-scan sonar imagery is rather uniform. However, at the offshore limit of the study area, very significant onshore directed transport vectors are calculated.

To evaluate the sedimentological and morphological findings, the results were compared with the results of models developed by HR Wallingford, Delft Hydraulics, the University of Liverpool and the International Centre for Coastal Resources Research (Barcelona). Generally, the models showed that the flooding and ebbing of the estuary dominate the flow during spring tide. The models showed a maximum flow velocity exceeding $2.5 \mathrm{~m} /$ $\mathrm{s}$ in the estuary throat ('jet-like outflow') whilst the offshore tidal flow speeds were less than $0.3 \mathrm{~m} / \mathrm{s}$. The flow models all produced a number of gyres or vortices during the emptying of the estuary and which were also observable in current meter records. In the spring tide case, the greatest calculated sediment transport rates were just outside the mouth of the estuary (Sutherland, 2000). The inflow is more evenly spread than the outflow and no vortices are shed. For a single wave case, wave height, wave direction, wavedriven currents and sediment transport rates were modelled. The models all produced a clockwise gyre on the north side of the tip of 'Spratt Sand' and an anticlockwise gyre to the east of 'The Ness' as well as a number of other gyres towards the estuary mouth and along the coast. Interestingly, the pattern of the modelled sediment transport vectors followed the pattern of the wave-induced current. The dominance of the wave-driven current is likely due to the rather weak longshore tidal current in Lyme Bay $(0.2-0.3 \mathrm{~m} / \mathrm{s})$.

Compared to the field observations, the modelling results show some interesting similarities. Both the sedimentological and morphological findings indicate the higher dynamics in the estuary mouth corresponding to the modelled jetlike outflow. The narrow estuary mouth is indeed composed of coarse-grained ripples indicative of intense selective transport processes. The 


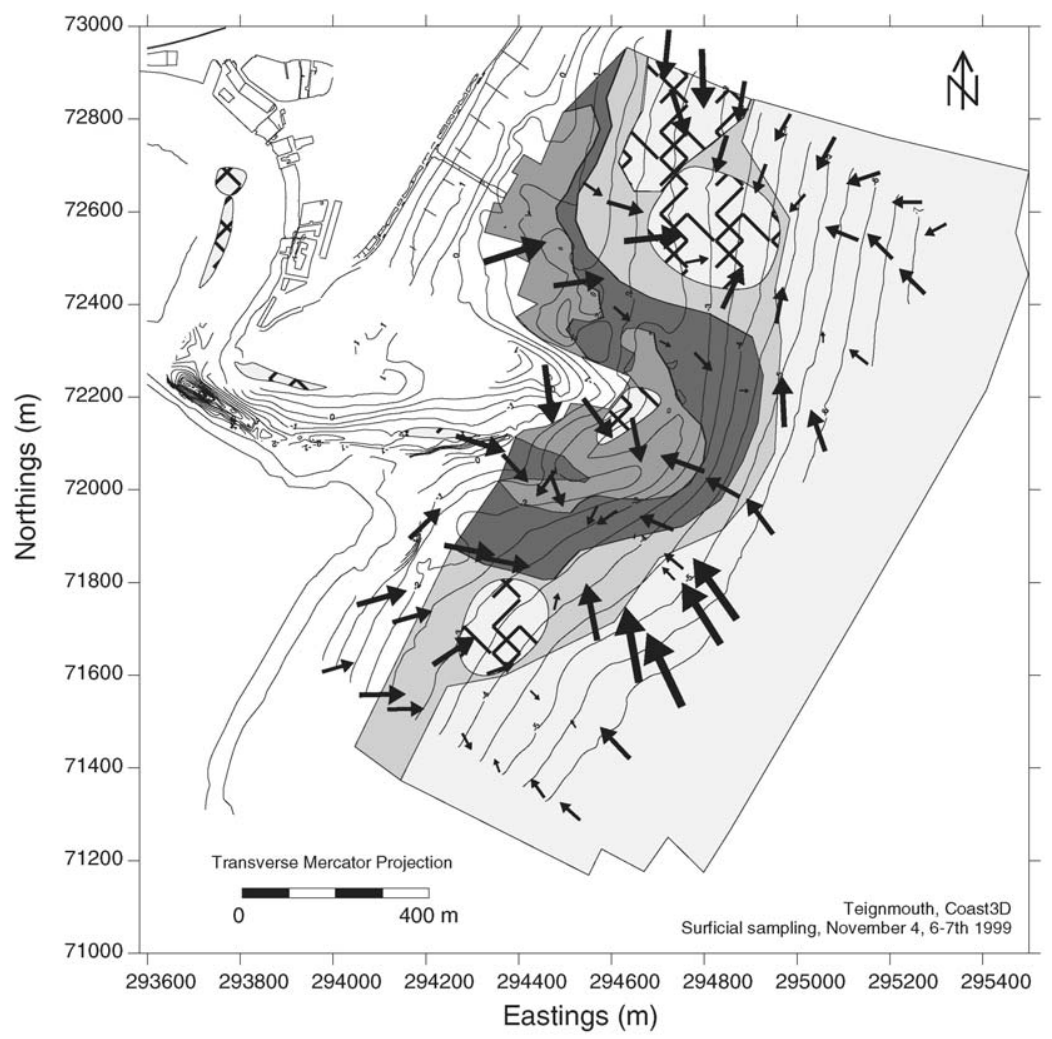

Fig. 22. Correlation of the results of the sediment trend analysis vectors on the interpreted bedform map derived from side-scan sonar observations on 4-5 November 1999.

calculated sediment transport vectors, inferred from the field observations, clearly point in an offshore direction.

Although refinement is needed, some correlation might exist between the larger modelled gyre structures associated with the strong outflow at the falling tide and the occurrence of bedforms in the nearshore. Especially, east of the estuary mouth, the occurrence of bedforms corresponds with a convergence of sediments as derived from the sediment trend analysis. Given more easterly directed significant transport vectors near 'Spratt Sand', the convergence might be associated with the modelled clockwise gyre structure.

It is thought that the southwestwards pointing transport vectors northeast of the study area reflect the normal littoral drift. Likely, they are also a reflection of an intensified sediment transport as the current is funnelled through the flood channel close to the beach. This channel is the result of the flood tide eddy causing more southerly than northerly flow and giving rise to sandbars that are highly mobile (Miles et al., 1997).

The transport vectors at the offshore limit of the study area, southeast of the estuary mouth, are more difficult to understand as they show a highly significant sediment transport in an onshore direction. An explanation is however sought, taking into account the hydro-meteorological conditions preceeding the sampling campaign of 4, 6-7 November.

In the pre-survey period, the high wind speeds were mainly generated from a south to northwestwards direction. From an offshore waverider buoy, it was shown that waves with a significant wave height exceeding $0.5 \mathrm{~m}$ had a mean incoming direction of $140-150^{\circ}$. Interestingly, this direction 
roughly corresponds with the angle of the sediment transport vectors at the offshore limit of the study area. Towards the coast, this wave direction is known to induce a north to northeastwards longshore current direction (Miles et al., 2000). This might explain the direction of the transport vectors offshore the rocky headland 'The Ness'.

\section{Conclusions}

A multi-disciplinary and international research project was set up to study the estuary-nearshore system of Teignmouth. The principal objective of the project was to carry out a combined field and modellers study of the hydrodynamical, morphological and sedimentological behaviour of the beach and nearshore area. In the present paper, emphasis was put on the sedimentological and morphological investigations in relation to the combined action of current and waves.

Teignmouth is characterised by semi-diurnal tides of macrotidal range and tidal currents. The narrow estuary mouth gives rise to strong jet-like current flows that typically attain $2 \mathrm{~m} / \mathrm{s}$ and gradually decreasing in an offshore direction. To the north, the mean currents are weak along the shoreface, however, a flood channel is present close to the beach and current velocities can exceed $1 \mathrm{~m} / \mathrm{s}$. The wave climate is mainly characterised by small, short period wind-driven waves. Fairly infrequent winds from the north to east are responsible for generating storm waves and generally result in a dominant longshore drift to the south.

The beach is composed of a reflective coarse steep upper beach and a dissipative fine sandy flat low-tide terrace. Following the parameterisation of Masselink and Short (1993) the beach is categorised as a low-tide terrace, reflective beach whereby the large tidal range has the effect of reducing bar formation in the region of the lowtide terrace, reducing the likelihood of rip currents and reducing the likelihood of cusp formation. Adjacent to the estuary mouth an intertidal shoal, 'Spratt Sand', is present that is morphologically active in terms of bedform mobility. The shape and orientation of the bedforms change with the tidal cycle, and due to wave activity, though their existence and their dimensions are constrained by sediment availability.

Although the beach and nearshore bank system are composed of mixed sediments, the offshore area is characterised by fine, well-sorted sands. The estuary mouth itself is composed of very coarse sands up to gravel size and its dynamics gives rise to three coarse-grained lobes, the position of which likely relates to shifts in the nearshore banks and channels. The observed grain-size distribution of these lobes results from selective transport processes arising from the reducing outflow velocities in a seaward direction. Hence, the area is characterised by deposition of coarse-grained bedload material, suspension fallout and reworking of the fine-grained deposits.

On the basis of the areal distribution of the mean, sorting and skewness of the surficial sediments, a sediment trend analysis was performed on the basis of the Gao and Collins (1992) procedure. The results show a significant residual transport along the sediment lobes in an offshore direction. However, a convergent transport pattern is seen northeast and southwest of the estuary mouth and interestingly also onshore directed transport vectors are calculated in the more offshore area. Digital side-scan sonar mosaicing allowed a detailed study of the small-scale morphology. The imagery showed that the coarse-grained lobes correspond with rippled areas. Oblique as well as cross-shore-oriented bedforms were seen including eastward pointing lunate megaripples in the estuary mouth. To the northeast and southwest of the ebb tidal delta, two zones were observed where bedforms can occur. The acoustic facies of the more offshore area merely has a patchy nature. This may reflect the presence of a submerged cliff line that is only covered by a thin veneer of sand; however, the imagery might also be biased by the presence of sediment bumps created by the trapping of sediments by dense faunal assemblages.

The sediment dynamical behaviour of Teignmouth area is discussed on the basis of repetitive beach surveying, chart differencing and from the side-scan sonar observations in combination with the sediment trend analysis. From the beach 
morphology changes, a rythmic alongshore beach behaviour could be distinguised. The alternating behaviour was attributed to the occurrence of two different periods of wave conditions. Previous investigations showed that incoming waves with significant wave heights larger than $0.5 \mathrm{~m}$ and a mean direction less than $140^{\circ}$ normally give rise to a southwards directed littoral drift whilst a northwards directed littoral drift results from a mean wave direction of more than $140^{\circ}$. From chart differencing, it was shown that longer lasting northeastern conditions can induce a general erosional trend. This was most apparent at the outer end of East Pole Sand, but also the bar running ENE from 'The Ness' had shifted in a northwards direction.

The results of the sediment trend analysis in combination with the distribution of the smallscale morphology confirmed the strong jet-like outflow velocities along the estuary mouth. It was also shown that the occurrence of bedforms outside the ebb tidal delta coincides with a convergence of sediment transport vectors or at least transport vectors with a higher level of significance meaning that sediment availability is the constraining factor for bedform development. Compared to the results from computer modelling, those zones might correspond with the location of gyres or vortices as a result of the emptying of the estuary. The models also showed that for a single wave case, the sediment transport followed the pattern of the wave-induced current. Since the period before the sampling campaign was characterised by stronger winds from the south to northwest sector, this could explain the northwestwards - onshore - and northeastwards directed transport vectors southwest of the estuary mouth. In contrast, it is thought that the transport vectors to the north of the estuary mouth are the result of the normal littoral drift processes and the presence of a flood channel.

The results confirm that the Teignmouth site is very dynamic and susceptible to a variety of processes that can be tide as well as wave dominated. Consequently, care should be taken interpreting sedimentological and morphological findings as different time-scales can be involved and the patterns are a response to fair-weather, tidally dominated, as well as storm-dominated processes.

\section{Acknowledgements}

The COAST3D project was funded partly by the European Commission's research programme MAST under Contract No. MAS3-CT97-0086 and partly through national funding from the UK Ministry of Agriculture Fisheries and Food research project FD0803, the UK Environmental Agency (R\&D Programme), the UK Natural Environment Research Council, and the Netherlands Rijkswaterstaat. The field work greatly benefited from mutual collaboration within the project team and the skill of the crew of the survey vessel MV 'Sir Claude Inglis', Melvyn Gofton (skipper) and Graham Pearson (1st Mate). We received excellent co-operation from many local organisations including Teignbridge District Council, Teignmouth Harbour Commission, Teign Fishermen and Watermen's Association and the Teignmouth Quay Company. Also the people of Teignmouth are thanked for their patience and friendly and co-operative attitude during the field work. Walewijn Muylle and the Research Unit of Sedimentary Geology and Engineering Geology of Ghent University are thanked for the analysis of the sediment samples. Finally, we wish to thank the referees for their comments on the manuscript.

\section{References}

Allen, J.R.L., 1968. Current Ripples. Their Relation to Patterns of Water and Sediment Motion. North-Holland Publ. Co., Amsterdam, 433pp.

Bell, P.S., 2000. X-Band radar results from the COAST3D Teignmouth main experiment, COAST3D. Overall Workshop. Caen June 2000.

Berne, S., Auffret, J.P., Walker, P., 1988. Internal structure of subtidal sandwaves revealed by high resolution seismic reflection. Sedimentology 35, 5-20.

BGS, 1983. Seabed Sediments Chart for Portland. British Geological Survey.

Burke, D., 1997. Use of photo-mosaics to monitor estuary mouth sandbanks. Unpublished M.Sc. Thesis, University of Plymouth, Plymouth. 
Carter, R.W.G., Balsillie, J.H., 1983. A note on the amount of wave energy transmitted over nearshore sand bars. Earth Surface Processes and Landforms 8, 213-222.

Craig-Smith, S.J., 1970. A hydrograpic analysis of the approaches to Teignmouth. Unpublished M.Sc. Thesis, University of Leicester, Leicester.

Davidson, M.A., Russell, P.E., Huntley, D.A., Hardisty, J., Cramp, A., 1993. An overview of the British beach and nearshore dynamics programme. In: Anonymous (Ed.), Proceedings of the 23rd International Conference on Coastal Engineering, Vol. 92, pp. 1987-2000.

Degraer, S., Van Lancker, V., Moerkerke, G., Vincx, M., Jacobs, P., Henriet, J.P., 2000. Research project: intensive evaluation of the evolution of a protected benthic habitat: habitat. In: Marine Habitat Committee (Ed.), Report of the Study Group on Marine Habitat Mapping. ICES, The Hague, NL, pp. 83-91.

Folk, R.L., Ward, W.C., 1957. Brazos river bar: a study in the significance of grain size parameters. Journal of Sedimentary Petrology 27 (1), 3-26.

Galvin, C.J.J., 1968. Breaker type classification in three laboratory beaches. Journal of Geophysical Research 73 (12), 3651-3659.

Gao, S., 1996. A fortran program for grain size trend analysis to define net sediment transport pathways. Computers and Geosciences 22 (4), 449-452.

Gao, S., Collins, M., 1992. Net sediment transport patterns inferred from grain-size trends, based upon definition of transport vectors. Sedimentary Geology 80, 47-60.

Gao, S., Collins, M.B., 1994. Analysis of grain-size trends, for defining sediment transport pathways in marine environments. Journal of Coastal Research 10 (1), 70-78.

Gao, S., Collins, M.B., Lanckneus, J., De Moor, G., Van Lancker, V., 1994. Grain size trends associated with net sediment transport patterns: an example from the Belgian Continental shelf. Marine Geology 121, 171-185.

Guza, R.T., Inman, D.L., 1975. Edge waves and beach cusps. Journal of Geophysical Research 80 (21), 2997-3012.

Hearn, S., Waters, C., Whitehouse, R., 2000. HR Wallingford data collection from Teignmouth, COAST3D. Overall Workshop. June 2000, Caen.

Hoekstra, P., Bell, P., Van Santen, P., Roode, N., Levoy, F., Whitehouse, R., 2004. Bedform migration and sediment transport on an intertidal shoal. Continental Shelf Research, this issue (doi:10.1016/j.csr.2004.03.006).

Hydraulics Research Station, 1958. Report on the situation in the harbour of Teignmouth and the stabilisation of the entrance channels. Unpublished Report.

Hydraulics Research Station, 1966. Teignmouth Harbourfluorescent tracer experiment. Unpublished Report.

Hydraulics Research Station, 1970. Teignmouth Harbour model study to investigate improvements to the harbour entrance and their influence on neighbouring beaches. Unpublished Report.

Konert, M., Vandenberghe, J., 1997. Comparison of laser grain size analysis with pipette and sieve analysis: a solution for the underestimation of the clay fraction. Sedimentology 44 (3), 523-535.
Kranck, K., Milligan, T.G., 1991. Grain size in oceanography. In: Syvitsky, J.P.M. (Ed.), Principles, Methods, and Application of Particle Size Analysis. Cambridge University Press, Cambridge, MA, pp. 332-346.

Levoy, F., Degryse, C., Monfort, O., 2000. Results obtained by the University of Caen during the Teignmouth main experiment, COAST3D. Overall Workshop, June 2000, Caen.

Malvern Inc., 1986. Malvern Instruments. Particle sizer. Reference Manual. Malvern Inc, Southboro.

Masselink, G., Short, A., 1993. The effect of tide range on beach morphodynamics and morphology: a conceptual beach model. Journal of Coastal Research 9 (3), 785-800.

Miles, J.R., Russell, P.E., Huntley, D.A., 1996. Sediment transport and wave reflection near a seawall. In: ASCE (Ed.), Proceedings of the 25th International Conference on Coastal Engineering. ASCE, Orlando, FL, pp. 2612-2624.

Miles, J., Russell, P.E., Huntley, D., 1997. Introduction to the Coast3D field study site at Teignmouth. Egmond, NL.

Miles, J.R., Russell, P.E., Huntley, D.A., 2000. Surf zone hydrodynamics at Teignmouth main experiment, COAST3D. Overall Workshop, June 2000, Caen.

Osborne, P.D., Vincent, C.E., 1993. Dynamics of large and small scale bedforms on a macrotidal shoreface under shoaling and breaking waves. Marine Geology 115, 207-226.

Rennie, J., 1838. Report on proposals for maintaining and improving the port of Teignmouth. Unpublished Report.

Robinson, A.H.W., 1975. Cyclical changes in shoreline development at the entrance to Teignmouth Harbour, Devon, England. In: Hails, J., Carr, A. (Eds.), Nearshore Sediment Dynamics and Sedimentation. Wiley, London, pp. 181-200.

Sea Sediments, 1979. A sedimentological survey of the Teign Estuary. Part 1, the bathymetry of the Teign Estuary, 1979; Part 2, a study of the distribution and dynamics of the sediments in the Teign Estuary, 1979; and, Part 3, an investigation of sewage contamination in the Teign Estuary, 1979. Reports prepared for Teignbridge District Council Planning Department by Sea Sediments (Dr. Rob Nunny), Laurence House, Affpuddle, Dorset.

Seward-Thompson, B.L., Hails, J.R., 1973. An appraisal of the computation of statistical parameters in grainsize analysis. Sedimentology 20, 161-169.

Soulsby, R., 1997. Dynamics of Marine Sands. A Manual for Practical Applications. Thomas Telford Publishing, London, 249pp.

Soulsby, R.L., 1998. Coastal sediment transport: the COAST3D project. Proceedings of the 26th International Conference on Coastal Engineering. ASCE, Copenhagen, pp. $2548-2558$.

Soulsby, R.L., 2000. Coastal study of three-dimensional sand transport processes and morphodynamics. Coast3D. In: C.R.E. European Commission, Environment and Sustainable Development (Ed.), EurOCEAN 2000 Conference, Hamburg.

Spratt, T., 1856. An Investigation of the Movements of Teignmouth Bar. John Weale, London. 
Sutherland, J., 2000. COAST3D Modelling of Teignmouth Pilot experiment, COAST3D. Overall Workshop, June 2000, Caen.

Thornton, E.B., Swayne, J.L., Dingler, J.R., 1998. Small-scale morphology across the surf zone. Marine Geology 145 (3-4), 173-196.

Van Lancker, V.R.M., Jacobs, P., 2000. The dynamical behaviour of shallow-marine dunes. In: Trentesaux, A., Garlan, T. (Eds.), Marine Sandwave Dynamics, International Workshop. University of Lille 1, Lille, FR, France, pp. 213-220.

Van Lancker, V.R.M., Honeybun, S.D., Moerkerke, G., 2000. Sediment transport pathways in the Broers Bank-Westdiep coastal system. Preliminary results. In: Trentesaux, A., Garlan, T. (Eds.), Marine Sandwave Dynamics, International Workshop. University of Lille 1, Lille, FR, France, pp. 205-212.

Van Lancker, V., Lanckneus, J., Martens, C., Moerkerke, G., 2001. Sediment transport in the nearshore area of Egmondaan-Zee (NL). Coastal Dynamics 2001, 11-15 June 2001, Lund, SE, pp. 1-10.
Walstra, D.J.R., Van Ormondt, M.,Van Rijn, L.C., 2000. Verification and comparison of the Delft3D-model for an inlet system (Teignmouth, UK), COAST3D. Overall Workshop, June 2000, Caen.

Wesseling, C., 1999. Manual DT2D Version 2.2; Software for Dune-tracking in Two Dimensions Utrecht University, ESE, Utrecht (in Dutch).

Whitehouse, R., Waters, C., 2000. COAST3D Teignmouth experiment. An overview of the main experiment. OctoberNovember 1999, COAST3D. Overall Workshop, June 2000, Caen.

Whitehouse, R., Hearn, S., Waters, C., Sutherland, J., 2000. Data report on measurements by HR Wallingford at Teignmouth UK (1998-1999). Report TR105, HR Wallingford, Wallingford.

Wimpol, 1989. Environmental survey and mathematical modelling of the river Teign estuary and coastal region. Unpublished Report. 